Review

\title{
Regeneration of catalysts deactivated by coke deposition: A review
}

\author{
Jibin Zhou a,b, Jianping Zhao a,b, Jinling Zhang a , Tao Zhang a, Mao Ye a,*, Zhongmin Liu a \\ a National Engineering Laboratory for Methanol to Olefins, Dalian National Laboratory for Clean Energy, iChEM (Collaborative Innovation Center of \\ Chemistry for Energy Materials), Dalian Institute of Chemical Physics, Chinese Academy of Sciences, Dalian 116023, Liaoning, China \\ b University of Chinese Academy of Sciences, Beijing 100049, China
}

\section{A R T I C L E I N F O}

\section{Article history:}

Received 30 September 2019

Accepted 16 November 2019

Published 5 July 2020

\section{Keywords: \\ Catalyst \\ Coke \\ Deactivation \\ Regeneration \\ Oxidation \\ Gasification \\ Hydrogenation}

\begin{abstract}
A B S T R A C T
In industrial catalytic processes, coke deposition can cause catalyst deactivation by covering acid sites and/or blocking pores. The regeneration of deactivated catalysts, thereby removing the coke and simultaneously restoring the catalytic activity, is highly desired. Despite various chemical reactions and methods are available to remove coke, developing reliable, efficient, and economic regeneration methods for catalytic processes still remains a challenge in industrial practice. In this paper, the current progress of regeneration methods such as oxidation (air, ozone and oxynitride), gasification (carbon dioxide and water steam), and hydrogenation (hydrogen) is reviewed, which hopefully can shed some light on the design and optimization of catalysts and the related processes.
\end{abstract}

(C) 2020, Dalian Institute of Chemical Physics, Chinese Academy of Sciences. Published by Elsevier B.V. All rights reserved.

\section{Introduction}

More than 80 percent of chemical processes in the various industrial sectors use catalysts, either to improve the reaction rates or for on-purpose synthesis of certain products. One of the drawbacks of industrial catalysts is the unavoidable deactivation over time on stream, accompanied by the loss in catalytic activity and product selectivity [1-4]. Hence, for the design and operation of a catalytic process, catalyst deactivation has to be addressed carefully [5,6]. Many intrinsic mechanisms are known to cause catalyst deactivation, but fundamentally they all can be categorized into six major types $[1,7,8]$ : (1) poisoning due to the chemisorption of certain species on the active sites; (2) fouling due to coke deposition; (3) thermal degradation; (4) vapor compound formation and/or leaching accompanied by molecular transport from the catalyst surface; (5) vapor-solid and/or solid-solid reactions; and (6) attrition and/or crushing. Some of these mechanisms might lead to permanent deactivation while others might only cause a temporary loss of catalytic activity. The mechanisms underlying catalyst deactivation have been reviewed previously [1-3,7].

Catalyst deactivation is an ongoing concern for industrial catalytic processes [2], and it is of practical and economic relevance to regenerate deactivated catalysts and restore their activity. Therefore, the development of reliable, efficient, and economic catalyst regeneration methods has attracted considerable attention. In this paper, we will review regeneration methods to restore the activity of catalysts deactivated by coke deposition, because this deactivation is of major concern in the petrochemical industry. Coke formation proceeds through chemical steps but also involves the retention of coke species in the pores and on the external surface of catalysts [9,10]. Exten-

\footnotetext{
* Corresponding author. Tel: +86-411-84379618; E-mail: maoye@dicp.ac.cn

This work was supported by the National Natural Science Foundation of China (91834302).

DOI: 10.1016/S1872-2067(20)63552-5 | http://www.sciencedirect.com/science/journal/18722067 | Chin. J. Catal., Vol. 41, No. 7, July 2020
} 
sive research has been done to understand the coke formation mechanisms [11-14]. It is generally accepted that coke formation follows three steps, i.e., hydrogen transfer at acid sites, dehydrogenation of adsorbed hydrocarbons, and polycondensation [12]. In principle, coke may affect catalyst activity in two ways: through active site coverage (poisoning) and pore blockages (active sites rendered inaccessible to reactants) [11]. The type of coke depends on the catalyst and reaction conditions, and thus regeneration methods vary according to the catalytic processes involved $[9,10]$. A lot of effort to date goes into coke prevention to extend catalyst lifetime $[9,10,15,16]$, but catalyst deactivation is still inevitable and occurs in a few seconds (fluid catalytic cracking, FCC) or over many years (ammonia synthesis) [4]. Moreover, the time required to regenerate a specific catalyst depends largely on the coke formation rate. Continuous catalyst regeneration becomes an economic necessity if the coke formation is rapid [2].

Restoring the activity of a permanently deactivated catalyst with standard regeneration procedures is difficult. Fortunately, catalyst deactivation due to coke deposition is usually reversible, and the coke can easily be removed by oxidation with air $\left(\mathrm{O}_{2}\right)[3,8,11]$. Indeed, in most industrial processes, coke is typically burned off with air to reactivate the spent catalyst. However, one of the challenges is the exothermicity of coke burning, which may cause hot spots, local high temperature gradients, and eventually cause damage to the catalyst $[2,17]$. Another challenge is that residual coke can change from aliphatic to aromatic coke during oxidation, making the regeneration more complex [18]. Several improved regeneration methods can remove coke at low temperature, maximizing regeneration efficiency with minimum catalyst destruction. For example, ozone $\left(\mathrm{O}_{3}\right)$ is used to regenerate coked ZSM-5 catalysts at low temperatures [19]. Solvent extraction methods have also been applied to remove coke at low temperatures [20,21]. Supercritical fluid extraction has, due to unique solvent and transport properties, shown potential to extract coke from porous matrices and specifically heterogeneous catalysts [22-24]. To meet the concept of "green carbon science" and use the benefits of the coke deposited, catalyst regeneration combined with coke gasification using $\mathrm{H}_{2} \mathrm{O}$ or $\mathrm{CO}_{2}$ has also been explored. Synthesis gas, instead of $\mathrm{CO}_{2}$, is the main product in these regeneration processes [25]. In certain cases, non-oxidative treatments, such as $\mathrm{H}_{2}$ sweeping, are used to remove coke from deactivated catalysts [26,27].

Each regeneration method has its advantages and disadvantages, depending on catalyst type, deactivation mechanisms and regeneration conditions. In this paper we will discuss recent advances in coke removal using oxidation (air/ $\mathrm{O}_{2}, \mathrm{O}_{3}$ and $\left.\mathrm{NO}_{x}\right)$, gasification $\left(\mathrm{CO}_{2}, \mathrm{H}_{2} \mathrm{O}\right)$ and hydrogenation $\left(\mathrm{H}_{2}\right)$. The aim of this review is to better understand each regeneration method discussed, and provide more insights into the most suitable regeneration method in the design and optimization of catalysts and the relevant processes.

\section{Regeneration using oxidation}

\subsection{Air/oxygen combustion}

The most frequently used method to regenerate coked catalysts is oxidation, using air or oxygen [7,9]. Applications are applied in industrial processes such as FCC [28,29], hydrotreating [6], catalytic reforming [30] and methanol to olefins (MTO) [31]. Coke oxidation can be typically represented by the following reactions [32,33]:

$$
\begin{aligned}
& 2 \mathrm{H}(\mathrm{s})+1 / 2 \mathrm{O}_{2}(\mathrm{~g}) \rightarrow \mathrm{H}_{2} \mathrm{O}(\mathrm{g}) \\
& (\mathrm{s})+\mathrm{O}_{2}(\mathrm{~g}) \rightarrow \mathrm{CO}_{2}(\mathrm{~g}) \\
& \mathrm{C}(\mathrm{s})+1 / 2 \mathrm{O}_{2}(\mathrm{~g}) \rightarrow \mathrm{CO}(\mathrm{g}) \\
& \mathrm{CO}(\mathrm{g})+1 / 2 \mathrm{O}_{2}(\mathrm{~g}) \rightarrow \mathrm{CO}_{2}(\mathrm{~g}) \\
& -121.0 \mathrm{~kJ} / \mathrm{mol} \\
& -395.4 \mathrm{~kJ} / \mathrm{mol} \\
& -110.4 \mathrm{~kJ} / \mathrm{mol} \\
& -285.0 \mathrm{~kJ} / \mathrm{mol}
\end{aligned}
$$

Coke oxidation is an exothermic process (Eqs. (1)-(4)) with $\mathrm{H}_{2} \mathrm{O}, \mathrm{CO}_{2}$ or $\mathrm{CO}$ as the main products in the flue gas. In some industrial processes such as FCC, the heat generated by coke oxidation compensates for the heat needed for the endothermic cracking reactions, and favors the heat balance between reactor and regenerator. In other industrial processes such as MTO, however, the exothermicity of both methanol conversion and coke oxidation makes it a complicated task to remove the excess heat in the reactor-regenerator system. In addition, water as a regeneration product may cause catalyst dealumination due to the thermal and hydrothermal instability of most catalysts at high temperature [32]. This is in particular relevant to fixed-bed reactors, because of their poor heat transfer capacity. The temperature of the catalyst bed can rise steeply and cause temperature runaways [34].

The rate of coke removal during air combustion is dependent on catalyst type. Magnoux et al. [35] compared the coke oxidation of different catalyst types in air and found that the coke oxidation rates of $\mathrm{HY}$ and H-mordenite were faster than that of HZSM-5. They attributed the rate difference to the pore structure of catalysts, because the pore structure affects the $\mathrm{O}_{2}$ diffusion, which subsequently affects the contact between coke and $\mathrm{O}_{2}$, inducing shape-selectivity onto the coke oxidation process [35]. Similarly, it was observed that the coke oxidation rate of HFAU-type catalysts was higher than that of the HEMT type, regardless of framework composition and coke content. This is because the coke deposited on HFAU catalysts was preferentially deposited on the outer surface and easily accessible to $\mathrm{O}_{2}$ [36].

Acid sites also affect coke removal during regenerations. Jong et al. [27] studied the regeneration of coked HZSM-5 ethylbenzene conversion catalysts in air. They found that coke deposited in the intracrystalline channels near the Brønsted acid sites was removed prior to that on the external surface. In this case, alkylated polyaromatic carbonaceous compounds were converted into a more condensed aromatic structure during coke oxidation [27]. Guisnet et al. [37] showed that the density of HY framework aluminum atoms, i.e., the density of acid sites, could alter the rate of coke oxidation.

The coke oxidation rate is also influenced by the nature of coke. Auguayo et al. [38] showed that the H/C ratio of deactivated HZSM-5 catalysts would decrease after sweeping with He. And the activation energies of these catalysts regenerated with air combustion, would increase compared to that of deactivated catalyst without sweeping [38]. This holds also true for SAPO-34 catalysts, coked at different reaction conditions and treated with air combustion [39]. Ortege et al. [40] reported 
that the combustion kinetics were related to the $\mathrm{H} / \mathrm{C}$ of the coke deposited on HZSM-5 catalyst in methanol to gasoline process. The activation energy increased from 68.2 to 170 $\mathrm{kJ} / \mathrm{mol}$, with the $\mathrm{H} / \mathrm{C}$ ratio decreasing from 2.35 to 0.48 . Chen et al. [41] investigated the combustion kinetics of deactivated ZSM-5/MOR catalysts used in n-heptane cracking and found a relationship between the $\mathrm{H} / \mathrm{C}$ ratio and activation energy. The lower the $\mathrm{H} / \mathrm{C}$ ratio, the more difficult it was to remove the coke, suggesting higher activation energies. In summary, coke oxidation rates depend on several factors, such as pore structure, catalyst acidity, coke property, and coke location.

Due to the complex coke composition, pyrene was impregnated on HY zeolites and used as a model to study coke combustion behavior. Moljord et al. [42] proposed that three types of reactions occured during the oxidation of pyrene trapped in HY catalysts: (a) condensation of polyaromatic molecules, (b) oxidation of polyaromatics into oxygenated compounds and (c) decarbonylation or decarboxylation of oxygenated compounds. In a regeneration study of a deactivated ferrierite-type zeolite, Keskitalo et al. [43] found that the formation of the oxygenated intermediate was a fast equilibrium reaction. Meanwhile, Magnoux et al. [35] discovered that, regardless of the properties of catalyst and coke, the combustion always started with hydrogen removal, yielding water and oxygenated intermediates, which subsequently decomposed into $\mathrm{CO}$ and $\mathrm{CO}_{2}$, or being completely oxidized into $\mathrm{CO}_{2}$ and $\mathrm{H}_{2} \mathrm{O}$. This was verified by the evolution of $\mathrm{H}_{2} \mathrm{O}, \mathrm{CO}_{2}$ and $\mathrm{CO}$ using a stepwise temperature program in air, as shown in Fig. 1. At temperatures lower than $300{ }^{\circ} \mathrm{C}$, a large quantity of water was formed, while at temperature higher than $500{ }^{\circ} \mathrm{C}$ only $\mathrm{CO}_{2}$ and $\mathrm{CO}$ were observed [37]. Nakasaka et al. [44] employed the multiple-reaction model to analyze the regeneration of coked MFI-type zeolite after catalytic cracking of $n$-hexane. The activation energies of carbon and hydrogen were 156 and $140 \mathrm{~kJ} / \mathrm{mol}$, respectively. These results all proved that the coke oxidation was initiated by hy-

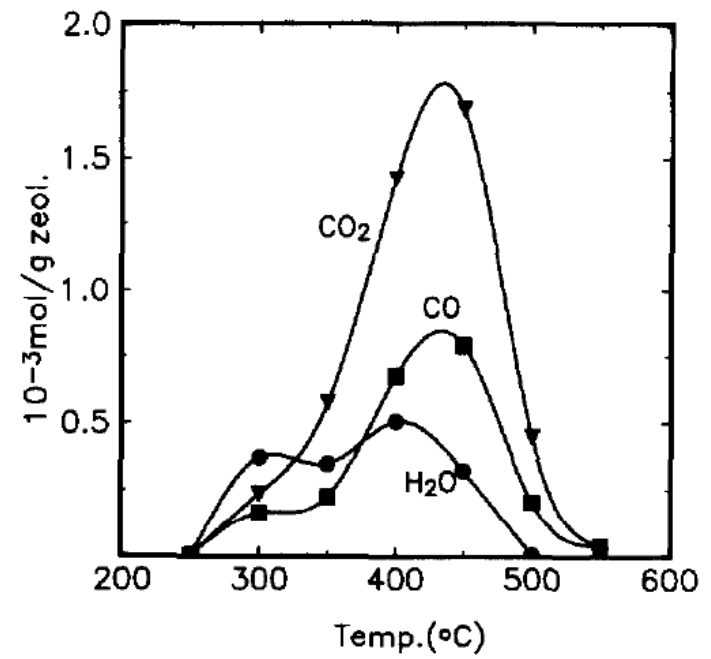

Fig. 1. Evolution of $\mathrm{H}_{2} \mathrm{O}, \mathrm{CO}$, and $\mathrm{CO}_{2}$ as function of oxidation temperature. Tests were carried out in a fixed-bed reactor using a stepwise temperature program in the range of 250 to $550{ }^{\circ} \mathrm{C}$. The $\mathrm{H}_{2} \mathrm{O}$ and $\mathrm{CO}_{2}$ evolved were trapped by anhydrone and ascarite traps, respectively [37], Copyright (1995) Elsevier. drogen removal, followed by removal of carbon.

Coke oxidation is a strongly exothermic reaction and the released heat may lead to irreversible catalyst damages. Temperature reduction becomes critical in order to avoid thermal damage during coke regeneration. An effective way is to modify the catalysts with metals. Numerous studies had been devoted to understand the effect of additional metal on coke oxidation [45-49]. Kozhevnikov et al. [49] modified silica-supported heteropoly acids with $\mathrm{Pd}$ and found the catalyst regeneration temperature was reduced from 450 to $350{ }^{\circ} \mathrm{C}$. Moreover, coke located close to the metal is much easier to remove, while coke located on the support requires longer regeneration time and higher temperatures to be removed [50,51]. When Aguayo et al. [52] studied the regeneration of coked $\mathrm{CuO}-\mathrm{ZnO}-\mathrm{Al}_{2} \mathrm{O}_{3} / \gamma-\mathrm{Al}_{2} \mathrm{O}_{3}$ catalysts using temperature-programmed oxidation (TPO), they observed two peaks. The first peak at $260{ }^{\circ} \mathrm{C}$ was attributed to the combustion of coke deposited on metal sites, while the second peak at $400{ }^{\circ} \mathrm{C}$ corresponded to the combustion of coke associated with acid sites. Adding Pt and Gd to ZSM-5 catalysts enhanced the coke oxidation ability and synergistic effects were also observed. The maximum oxidation temperatures of ZSM-5, Gd/ZSM-5, Pt/ZSM-5 and Pt-Gd/ZSM-5 were $618,583,517$, and $492^{\circ} \mathrm{C}$, respectively (Fig. 2) [47].

Although metal-modified catalysts can promote the coke combustion rate and reduce the regeneration temperature, it also has its disadvantages. For example, the catalyst stability and regenerability cannot be guaranteed. Furusawa et al. [53] used a $\mathrm{Ni} / \mathrm{MgO}$ catalyst for steam reforming of naphthalene/benzene. The catalyst activity was stable from the first until the third cycle, but then suddenly decreased in the fourth cycle. Similarly, Lu et al. [54] investigated the regeneration cycle stability of a Ni $/ \gamma-\mathrm{Al}_{2} \mathrm{O}_{3}$ catalyst for toluene cracking. The cracking was carried out at $700{ }^{\circ} \mathrm{C}$ for $0.5 \mathrm{~h}$, followed by air combustion at $600{ }^{\circ} \mathrm{C}$ for $3 \mathrm{~h}$. The cycle performance is shown in Fig. 3. Although the regeneration could recover the $\mathrm{H}_{2}$ yield to a certain extent, the yields gradually decreased after each

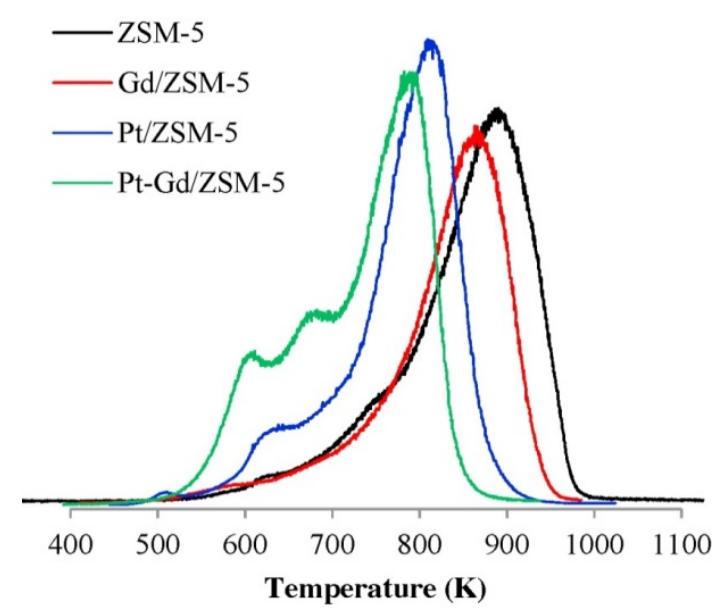

Fig. 2. TPO profiles of metal-modified ZSM- 5 catalysts deactivated after cracking for $10 \mathrm{~h}$ at $450{ }^{\circ} \mathrm{C}$. The deactivated catalysts were pretreated with $\mathrm{He}$ at $200{ }^{\circ} \mathrm{C}$ to dry and remove volatile compounds before the oxidation step. The system was then heated at a ramping rate of 20 ${ }^{\circ} \mathrm{C} \cdot \mathrm{min}^{-1}$ under a flow of $10 \mathrm{~cm}^{3} \cdot \mathrm{min}^{-1}$ of $10 \% \mathrm{O}_{2}$, balanced with $\mathrm{He}$ [47] Copyright (2014) Elsevier. 


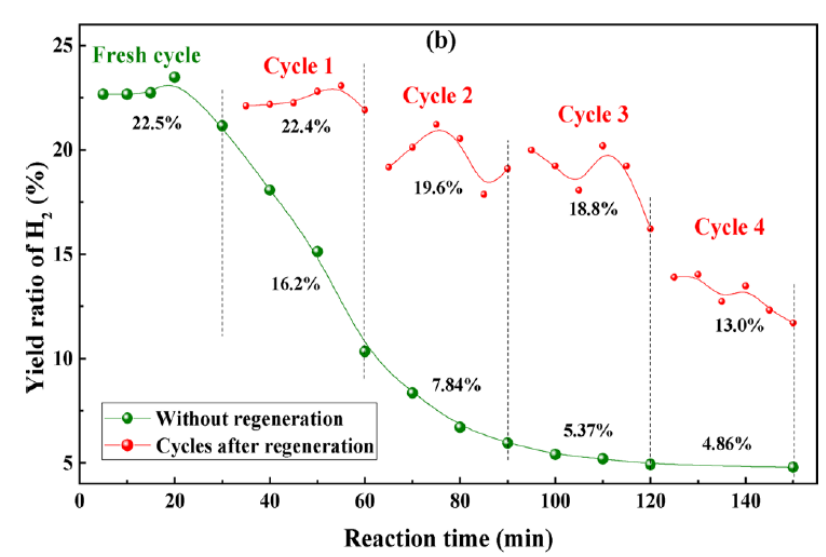

Fig. 3. $\mathrm{H}_{2}$ yield with time on stream and different cycles. Cracking tests lasted for $0.5 \mathrm{~h}$ at $700{ }^{\circ} \mathrm{C}$. Then the catalyst was cooled to $600^{\circ} \mathrm{C}$ and oxidized in air for $3 \mathrm{~h}$ using the same experimental apparatus. The regeneration and cracking tests were conducted four times, defined as cycle 1 to cycle 4 [54], Copyright (2017) American Chemical Society.

cycle, explained by Ni sintering and graphitized residual coke.

In addition to metal modification, alternative strategies to limit high temperatures have also been proposed. In industrial practice, regeneration temperatures are typically controlled by adjusting the $\mathrm{O}_{2}$ concentration. Steam, sometimes nitrogen, is used as a diluent in industrial-scale plants [2]. Moreover, a two-stage regeneration system has been developed and is used in FCC units [55-57], because hydrogen-rich fractions of coke significantly contribute to heat production and react easily with $\mathrm{O}_{2}$. The first stage operates at a temperature just enough to remove these hydrogen-rich coke. The second stage operates at a higher temperature to remove the more stable residual coke [32]. Owing to the relatively low temperature of the first stage and low water partial pressure in the second stage, structural changes to the catalysts are minimized [9].

In conclusion, to regenerate coked catalysts with air combustion is often the preferred and most practical route. However, high exothermicity can easily cause overheating, leading to dealumination, metal sintering, and catalyst degradation. Therefore, developing an efficient but milder regeneration method is of particular interest.

\subsection{Ozone/oxynitride oxidation}

Owing to its strong oxidizing properties, $\mathrm{O}_{3}$ can remove coke from catalysts at a much lower temperature $\left(50-200{ }^{\circ} \mathrm{C}\right.$ ) [18,58-61]. Copperthwaite et al. [58] showed that regeneration with ozone-enriched oxygen $\left(\mathrm{O}_{3} / \mathrm{O}_{2}\right.$ mole ratio of 0.05$)$ restored the catalytic activity of deactivated ZSM-5 methanol conversion catalysts at $150{ }^{\circ} \mathrm{C}$ in $90 \mathrm{~min}$. Compared to $\mathrm{O}_{2}$ reactivation a slightly increased lifetime but reduced initial methane yield were observed. Mariey et al. [61] reported that coke deposited on $\mathrm{HY}$ catalysts could be removed by $\mathrm{O}_{3}$ at $180{ }^{\circ} \mathrm{C}$ or lower. While for $\mathrm{O}_{2}$ regeneration, a temperature higher than $500{ }^{\circ} \mathrm{C}$ was needed. Studying $\mathrm{O}_{3} / \mathrm{O}_{2}$ regeneration of coked $\mathrm{HY}$ catalysts, Hutchings et al. [55] regenerated coked catalysts with ozone-enriched oxygen at $250{ }^{\circ} \mathrm{C}$ without risk of hydrothermal degradation. However, the coke located in the center of the extrudates was not removed due to pore diffusion limitations and rapid $\mathrm{O}_{3}$ dissociation.

For supported metal catalysts, metal segregation and sintering are almost inevitable after repeated regenerations using air combustion at high temperatures. To ensure catalyst stability during regeneration, common practice is to remove the coke at low temperature. For example, Pieck et al. used $\mathrm{O}_{3}$ as regeneration medium to remove coke from $\mathrm{Pt}-\mathrm{Re} / \gamma-\mathrm{Al}_{2} \mathrm{O}_{3}[60,62]$ and Pt-Sn $/ \gamma-\mathrm{Al}_{2} \mathrm{O}_{3}$ [63] catalysts almost at room temperature, with a maximum at $150-160{ }^{\circ} \mathrm{C}$. Moreover, they observed that coke removal with $\mathrm{O}_{2}$ starts on the metal sites, while that with $\mathrm{O}_{3}$ starts on the alumina support [63]. Furthermore, temperatures higher than $150{ }^{\circ} \mathrm{C}$ were not beneficial due to the strong diffusion constraints of $\mathrm{O}_{3}$ inside the zeolite particles, decomposing $\mathrm{O}_{3}$ rapidly [64]. Khangkham et al. [65] investigated the regeneration of coked ZSM-5 after polymethyl methacrylate cracking, using $\mathrm{O}_{3}$ at low temperature. They determined that at higher temperature the $\mathrm{O}_{3}$ decomposition rate was faster than its diffusion rate, leading to a significant reduction of the overall oxidation rate.

In summary, coke removal using $\mathrm{O}_{3}$ oxidization at low temperature is an efficient process [66] with a low risk of hydrothermal degradation, dealumination and metal sintering. However, $\mathrm{O}_{3}$ oxidization also has its drawbacks. On the one hand, it is difficult to remove coke from the center of catalyst particles, because of rapid $\mathrm{O}_{3}$ dissociation. On the other hand, the extensive use of $\mathrm{O}_{3}$ in industrial processes is limited, because $\mathrm{O}_{3}$ emissions are strictly controlled to a maximum of $75 \mathrm{ppb}$, to avoid damaging the atmosphere [32].

Despite $\mathrm{O}_{3}, \mathrm{NO}_{x}$ are also potential and cheap oxidization agents, able to remove coke at low temperatures. Ivanov et al. [67] reported that $\mathrm{N}_{2} \mathrm{O}$ was more efficient than $\mathrm{O}_{2}$ removing coke from ZSM-5, deposited during benzene-to-phenol oxidation reactions. Barbera et al. [68] used $\mathrm{NO}_{2}$ to regenerate $\mathrm{ZSM}-5$ catalysts deactivated during conversion of methanol to hydrocarbons. They discovered that coke, specifically coke on the external surface, could be removed at around $350-400{ }^{\circ} \mathrm{C}$, which temperatures were about $200{ }^{\circ} \mathrm{C}$ lower than that for regenerations using conventional air combustion. However, the ZSM-5 catalyst activity became unstable after regeneration with $\mathrm{NO}_{2}$ oxidation, which might be partially attributed to the redistribution of $\mathrm{Al}$ atoms and irreversible catalyst degradation during $\mathrm{NO}_{2}$ oxidization [68]. In this context, regeneration of coked catalysts using $\mathrm{NO}_{x}$ oxidation is not advanced enough and needs further research.

\section{Regeneration using gasification}

Although coke oxidization is widely employed to regenerate deactivated industrial catalysts, the coke cannot be valued and large amounts of $\mathrm{CO}_{2}$ are released. $\mathrm{CO}_{2}$ is a greenhouse gas causing significant environmental issues, such as global warming. For example, regeneration of spent catalysts with air combustion in FCC units produces about $40 \%-45 \%$ of $\mathrm{CO}_{2}$ emitted from refineries [69]. An alternative way to reduce $\mathrm{CO}_{2}$ emission is to regenerate the spent catalyst using gasification with $\mathrm{H}_{2} \mathrm{O}$ 
or $\mathrm{CO}_{2}$. The gasification of coked catalysts in FCC processes has been studied before [70-73].

\section{1. $\mathrm{CO}_{2}$ gasification}

Utilization of $\mathrm{CO}_{2}$ as feedstock has attracted increased interest owing to its positive impact on the global carbon balance [74]. $\mathrm{CO}_{2}$ can act as a mild oxidizing agent when reacting with coke, which is known as the Reverse Boudouard (RB) reaction [75], as shown in Eq. (5). Regeneration of coked catalysts via $\mathrm{CO}_{2}$ gasification can reduce $\mathrm{CO}_{2}$ to $\mathrm{CO}$, beneficial to the carbon footprint.

$$
\mathrm{C}(\mathrm{s})+\mathrm{CO}_{2}(\mathrm{~g}) \rightarrow 2 \mathrm{CO}(\mathrm{g})+172 \mathrm{~kJ} / \mathrm{mol}
$$

$\mathrm{CO}_{2}$ has been used for gasification of coal, biomass, and sewage sludge [76-78]. These resources are out of scope for this review and will not be discussed further. $\mathrm{CO}_{2}$ gasification is a highly endothermic reaction and normally takes place at temperatures above $700{ }^{\circ} \mathrm{C}[79]$, which conditions might destroy the catalyst structure and/or cause sintering [80]. Therefore, the low reactivity of $\mathrm{CO}_{2}$ and the high reaction temperatures needed are the two main limitations for catalyst regeneration using $\mathrm{CO}_{2}$ gasification [81]. Compared to steam gasification, $\mathrm{CO}_{2}$ gasification has still several advantages. Unlike steam, $\mathrm{CO}_{2}$ is a gas and thus requires no vaporization before gasification. In addition, steam can attack the Al-O bond of the catalyst at high temperature, which leads to the collapse of the catalyst framework [82-84]. This is not occurring in $\mathrm{CO}_{2}$ gasification.

The most widely used mechanism for uncatalyzed carbon- $\mathrm{CO}_{2}$ gasification follows a two-step oxygen exchange process [85]:

$$
\begin{aligned}
\mathrm{C}_{\mathrm{f}}+\mathrm{CO}_{2} & \leftrightarrow \mathrm{C}(\mathrm{O})+\mathrm{CO} \\
\mathrm{C}(\mathrm{O}) & \rightarrow \mathrm{CO}+\mathrm{C}_{\mathrm{f}}
\end{aligned}
$$

where $\mathrm{C}_{\mathrm{f}}$ is an available active site, and $\mathrm{C}(\mathrm{O})$ represents the reactive carbon-oxygen surface complex, i.e., an occupied active site. According to this mechanism, $\mathrm{CO}_{2}$ is first dissociated at a free active site and forms the carbon-oxygen complex, releasing a CO molecule. Then the carbon-oxygen complex produces a newly available active site and another CO molecule [85]. Freund et al. [86,87] studied $\mathrm{CO}_{2}$ gasification, uncatalyzed and with K-catalyst, and observed that the K-catalyst not only provided an active center for $\mathrm{CO}_{2}$ adsorption and dissociation but also increased the number of active sites, without changing the kinetic mechanism, in contrast to the uncatalyzed gasification $[86,87]$. In this section, however, we will mainly focus on the coke removal on different catalysts using $\mathrm{CO}_{2}$ gasification.

Santos et al. [70] investigated the regeneration of coked FCC catalysts under $\mathrm{CO}_{2} / \mathrm{He}$ atmosphere with temperature-programmed reaction from room temperature to $1000^{\circ} \mathrm{C}$. They found that the coke type had an obvious effect on the gasification rate. Aliphatic and poly-substituted aromatic species were prone to react with $\mathrm{CO}_{2}$. Moreover, $\mathrm{CO}_{2}$ gasification could be fitted well to a first-order kinetic model with temperature being varied from 600 to $940{ }^{\circ} \mathrm{C}$ [70]. Although the $\mathrm{O}_{2}$ reactivity is several orders of magnitude higher than that of $\mathrm{CO}_{2}, \mathrm{CO}_{2}$ gasification can still take place in the presence of $\mathrm{O}_{2}$, and even dominates the initial stage of the catalyst regeneration, dependent on the $\mathrm{CO}_{2}$ partial pressure [70]. In order to regener- ate the coked catalyst used for upgrading heavy petroleum feeds, Wang et al. [88] studied the gasification reactivity with $\mathrm{CO}_{2}$ at $800-900{ }^{\circ} \mathrm{C}$. Results showed that increasing temperature was favorable to improve the gasification rate, but the rate decreased significantly when the coke conversion increased above $50 \%$. This was in good agreement with the results of Santos et al. [70]. Coke deposited on the catalyst surface is removed first, followed by the coke deposited in the pores. In this case, Knudson diffusion gradually becomes dominant with proceeding reaction, leading to a decreasing gasification rate.

Although $\mathrm{CO}_{2}$ could react with coke at high temperatures, from a viewpoint of thermal stability, low gasification temperatures are desired. Previous studies showed that the $\mathrm{CO}_{2}$ gasification rate can be effectively promoted by additives [89]. For example, catalysts doped with metals can both increase the gasification rate and reduce the gasification temperature. However, it should be stressed that metals could poison and deactivate the catalyst. Therefore, the metal amounts should be small relative to the quantity of catalyst. Moreover, different metal additives may affect $\mathrm{CO}_{2}$ gasification differently, making the development of suitable metal additives a major challenge.

Mirzabekova et al. [90] studied the coke removal of cracking catalysts via $\mathrm{CO}_{2}$ gasification. They found that catalysts modified with $\mathrm{Mn}$ or La (5 wt\%) increased the average gasification rate almost 15 times compared to that of unmodified catalysts. Sun et al. [91] treated deactivated FeLi/ZSM-5 ethyl benzene conversion catalysts under $\mathrm{CO}_{2}$ atmosphere at $550{ }^{\circ} \mathrm{C}$ for $4 \mathrm{~h}$, and observed that the catalytic activity could be partially recovered. It has also been demonstrated that FCC regeneration processes can remove coke from deactivated alumina modified with vanadium, group I, and group II elements via $\mathrm{CO}_{2}$ gasification [71,75,92,93]. A study on the regeneration of deactivated $\mathrm{Al}_{2} \mathrm{O}_{3}, \mathrm{~K} / \mathrm{Al}_{2} \mathrm{O}_{3}, \mathrm{~V} / \mathrm{Al}_{2} \mathrm{O}_{3}$, and $\mathrm{V}-\mathrm{K} / \mathrm{Al}_{2} \mathrm{O}_{3}$ catalysts under $10 \%$ $\mathrm{CO}_{2} / \mathrm{He}$ atmosphere showed that the presence of $\mathrm{K}$ and $\mathrm{V}$ could enhance the gasification rate. The activation energy required for $\mathrm{CO}_{2}$ gasification was reduced from $349 \mathrm{~kJ} / \mathrm{mol}$ for $\mathrm{Al}_{2} \mathrm{O}_{3}$ to $249 \mathrm{~kJ} / \mathrm{mol}$ for $\mathrm{K} / \mathrm{Al}_{2} \mathrm{O}_{3}$, and further to $192 \mathrm{~kJ} / \mathrm{mol}$ for $\mathrm{V}-\mathrm{K} / \mathrm{Al}_{2} \mathrm{O}_{3}$ [75]. In another study, $\mathrm{CO}_{2}$ gasification, to remove coke from alkali (Li, $\mathrm{Na}$ and $\mathrm{K}$ ) and alkaline earth (Ca and $\mathrm{Mg}$ ) modified $\mathrm{Al}_{2} \mathrm{O}_{3}$ catalysts, was investigated. The gasification activity followed the order: $\mathrm{K}>\mathrm{Mg}, \mathrm{Li}>\mathrm{Ca}, \mathrm{Na}>$ pristine $\mathrm{Al}_{2} \mathrm{O}_{3}$ [92]. Perira et al. [93] explored the coke gasification with $\mathrm{CO}_{2}$ over alumina modified with $\mathrm{Na}, \mathrm{Ca}$ and $\mathrm{V}$. A synergism was observed for metal combinations such as $\mathrm{Na}-\mathrm{V}$ and $\mathrm{Ca}-\mathrm{V}$, resulting in a decrease in gasification temperature. This also proved that $\mathrm{V}$ played a significant role in $\mathrm{CO}_{2}$ activation. However, according to previous work [94], group I and II elements, and $\mathrm{V}$ can poison FCC catalysts. Hence, Pereira et al. [71] mixed $\mathrm{Li}-\mathrm{V} / \mathrm{Al}_{2} \mathrm{O}_{3}$ as an additive to spent USHY, and showed that lower $\mathrm{CO}_{2}$ gasification temperatures than that for the unmodified USHY catalyst can be applied. They also explored the proportional effect of additive addition on gasification temperature, as listed in Table 1. As the proportion of additive decreased, higher temperatures were required [71].

$\mathrm{CO}_{2}$ gasification has also been used for regenerating Ni-based catalysts from steam reforming of hydrocarbons [95]. $\mathrm{Xu}$ et al. [96] conducted comparative tests to regenerate coked 


\section{Table 1}

Maximum and initial $\mathrm{CO}$ formation temperatures and final coke loading for $\mathrm{RB}$ reaction of mechanical mixtures of $\mathrm{Li}-\mathrm{V} / \mathrm{Al}_{2} \mathrm{O}_{3}$ and USHY under $\mathrm{CO}_{2} / \mathrm{He}$ atmosphere. The coked samples $(100 \mathrm{mg})$ were heated from 25 to $1000{ }^{\circ} \mathrm{C}$ at a heating rate of $10{ }^{\circ} \mathrm{C} \cdot \mathrm{min}^{-1}$ under a flow of $10 \% \mathrm{CO}_{2}$ in $\mathrm{He}$ at $60 \mathrm{ml} \cdot \mathrm{min}^{-1}$. The $\mathrm{CO}$ flow was monitored with an on-line mass spectrometer [71], Copyright (2016) Elsevier.

\begin{tabular}{lccc}
\hline Sample & $T_{\max }{ }^{\mathrm{a}}\left({ }^{\circ} \mathrm{C}\right)$ & $T_{\min }{ }^{\mathrm{b}}\left({ }^{\circ} \mathrm{C}\right)$ & $\mathrm{Coke}_{\text {final }}(\%)$ \\
\hline $\mathrm{Li}-\mathrm{V} / \mathrm{Al}_{2} \mathrm{O}_{3}$ & 784 & 570 & traces \\
1 USHY: $1 \mathrm{Li}-\mathrm{V} / \mathrm{Al}_{2} \mathrm{O}_{3}$ & 879 & 647 & traces \\
1 USHY: $0.33 \mathrm{Li}-\mathrm{V} / \mathrm{Al}_{2} \mathrm{O}_{3}$ & 913 & 647 & traces \\
1 USHY: $0.2 \mathrm{Li}-\mathrm{V} / \mathrm{Al}_{2} \mathrm{O}_{3}$ & $>1000$ & 688 & traces \\
1 USHY: $0.1 \mathrm{Li}-\mathrm{V} / \mathrm{Al}_{2} \mathrm{O}_{3}$ & $>1000$ & 655 & traces \\
1 USHY: $0.05 \mathrm{Li}-\mathrm{V} / \mathrm{Al}_{2} \mathrm{O}_{3}$ & $>1000$ & 682 & 0.8 \\
USHY & $>1000$ & 706 & $1\left(19.1^{\mathrm{d}}\right)$ \\
\hline
\end{tabular}

aTemperature at which maximum CO formation was observed. ${ }^{\mathrm{b}} \mathrm{Tem}-$ perature at which $\mathrm{CO}$ starts to be formed. ${ }^{\mathrm{c}}<0.1 \%{ }^{\mathrm{d}}$ Initial coke loading.

$\mathrm{Ni}-\mathrm{Al}_{2} \mathrm{O}_{3}$ catalysts used in reforming of bio-oil with $\mathrm{CO}_{2}, \mathrm{H}_{2} \mathrm{O}$, and air, respectively. They found that $\mathrm{CO}_{2}$ was the best choice, as steam gasification would consume large quantities of $\mathrm{H}_{2} \mathrm{O}$ and air oxidization would cause catalyst sintering. However, the catalyst regenerated with $\mathrm{CO}_{2}$ gasification at $700{ }^{\circ} \mathrm{C}$ shows lower activity and stability than the fresh catalyst. Moreover, the activity and stability of regenerated catalysts gradually decreased with increasing reaction-regeneration cycles (Fig. 4). Bednarczuk et al. $[97,98]$ reported that the coke deposited on deactivated ethanol steam reforming $\mathrm{Ni}$ catalysts (with $\mathrm{Al}_{2} \mathrm{O}_{3}$, $\mathrm{MgO}, \mathrm{Y}_{2} \mathrm{O}_{3}, \mathrm{La}_{2} \mathrm{O}_{3}$ and $\mathrm{ZrO}_{2}$ supports) might be partly removed by $\mathrm{CO}_{2}$ gasification, accompanied by a partial recovery of catalyst activity.

Considering that $\mathrm{CO}$ is one of the products and $\mathrm{CO}_{2}$ is the reactant of dry reforming of methane (DRM), Vasconcelos et al. [99] investigated the regeneration of coked DRM Ni catalysts with $21 \% \mathrm{CO}_{2} / \mathrm{N}_{2}$ at $700{ }^{\circ} \mathrm{C}$. They showed that the catalyst activity could be fully recovered by regeneration in both $\mathrm{CO}_{2}$ and

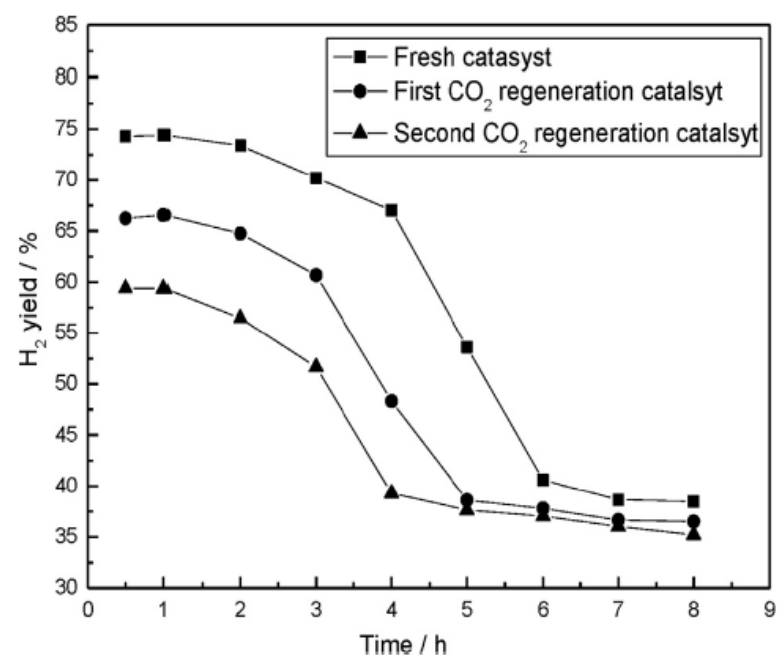

Fig. 4. Effect of reaction time on hydrogen yield of different catalysts. $\mathrm{CO}_{2}$ reforming of bio-oil was carried out in a fixed bed reactor, the reaction temperature was $700{ }^{\circ} \mathrm{C}$ and $\mathrm{CO}_{2} /$ bio-oil $=0.75$. The deactivated catalyst was regenerated in a stream of $\mathrm{CO}_{2}$, heating from room temperature up to $850{ }^{\circ} \mathrm{C}$ at $10^{\circ} \mathrm{C} / \mathrm{min}$, maintaining this temperature for 4 h [96], Copyright (2019) Elsevier. air. The group of Otsuka also studied the regeneration of coked methane decomposition $\mathrm{Ni}$ catalysts under $\mathrm{CO}_{2}$ atmosphere [100-102]. They envisioned that a zero $\mathrm{CO}_{2}$-emission process, in which the decomposition of methane is coupled with $\mathrm{CO}_{2}$ gasification, could be achieved [100]. A (5 wt\%) $\mathrm{Ni} / \mathrm{SiO}_{2}$ was used to study the repeatability of regeneration with methane decomposition at $530^{\circ} \mathrm{C}$ and coke gasification at $630{ }^{\circ} \mathrm{C}$. A decrease in hydrogen formation could be seen after two cycles, indicating poor regenerability. They ascribed the decrease of catalytic activity to the change of catalyst structures during the repeated reactions [100]. They also studied support effects $\left(\mathrm{SiO}_{2}, \mathrm{TiO}_{2}\right.$ and $\left.\mathrm{Al}_{2} \mathrm{O}_{3}\right)$ of $\mathrm{Ni}$ catalysts with methane decomposition at $550{ }^{\circ} \mathrm{C}$ and $\mathrm{CO}_{2}$ gasification at $650{ }^{\circ} \mathrm{C}$. Catalytic activity of $\mathrm{Ni} / \mathrm{TiO}_{2}$ and $\mathrm{Ni} / \mathrm{Al}_{2} \mathrm{O}_{3}$ could be sufficiently maintained during reaction-regeneration cycles [101], which suggested that in terms of regeneration performance, both $\mathrm{TiO}_{2}$ and $\mathrm{Al}_{2} \mathrm{O}_{3}$ are, in contrast to $\mathrm{SiO}_{2}$, excellent supports for those Ni catalysts [102].

$\mathrm{CO}_{2}$ gasification is highly endothermic and energy intensive, and $\mathrm{O}_{2}$ can be added to the $\mathrm{CO}_{2}$-rich atmosphere to achieve autothermic condition. The burning of coke with $\mathrm{O}_{2}$ supplies the energy required for the $\mathrm{CO}_{2}$ gasification [103]. Alenazey et al. [104] reported that the integration of air combustion and $\mathrm{CO}_{2}$ gasification could minimize energy usage, decrease greenhouse gas emission, and reduce catalyst sintering. This type of regeneration, using a rich $\mathrm{CO}_{2}$ atmosphere, is defined as one-stage FCC regeneration that is shown in Fig. 5 [92]. Here, $\mathrm{O}_{2}$ is obtained from an air separation unit and then mixed with $\mathrm{CO}_{2}$ to regenerate the spent catalyst. A large quantity of $\mathrm{CO}$ is produced, and the highly concentrated unreacted $\mathrm{CO}_{2}$ is recycled through the system [70,92,93].

Scheme 1 shows the reaction steps of the one-stage FCC regeneration system. The reaction of Scheme 1a is slightly endothermic while the reaction of Scheme $1 \mathrm{~b}$ is highly endothermic, since the oxidized groups decompose on a coke/graphite surface [105]. Scheme 1c represents the reaction of coke burning with $\mathrm{O}_{2}$, which can provide the energy demand for the overall FCC process, without increasing the temperature of the FCC

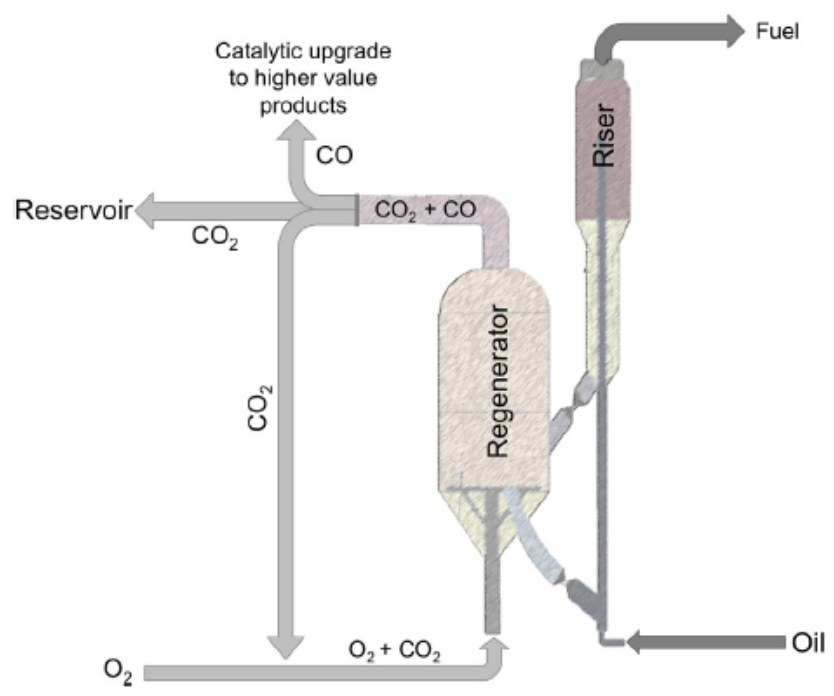

Fig. 5. One-stage FCC regeneration system under rich $\mathrm{CO}_{2}$ atmosphere [92], Copyright (2014) Elsevier. 


$$
\begin{array}{ll}
\mathrm{CO}_{2}+\text { Coke } \rightarrow \mathrm{CO}+\text { Coke-O } & 1-\mathrm{a} \\
\text { Coke-O } \rightarrow \mathrm{CO} / \mathrm{CO}_{2}+\text { Coke } & 1-\mathrm{b} \\
\text { Coke-O }+\mathrm{O}_{2} \rightarrow \mathrm{CO} / \mathrm{CO}_{2} & 1-\mathrm{c}
\end{array}
$$

Scheme 1. Reaction steps involved in FCC catalyst regeneration using a $\mathrm{CO}_{2} / \mathrm{O}_{2}$ atmosphere [93].

regenerator $\left(690-720{ }^{\circ} \mathrm{C}\right)$ [93]. However, since the oxidation reactivity of $\mathrm{O}_{2}$ is several orders of magnitude higher than that of $\mathrm{CO}_{2}$, this approach has not been applied practically [74].

To overcome the drawbacks of one-stage FCC regeneration in rich $\mathrm{CO}_{2}$ atmosphere, Silva et al. [92] proposed a two-stage FCC regeneration system, as shown in Fig. 6. In the first stage most of the coke is gasified with $\mathrm{CO}_{2}$ due to the high $\mathrm{CO}_{2}$ partial pressure and low $\mathrm{O}_{2}$ concentration. In the second stage the residual coke is further oxidized with $\mathrm{O}_{2}$ at a higher partial pressure and provides heat to the first stage as well as the overall FCC process. Hettinger et al. [106] envisioned a similar stepwise regeneration system. The only difference is that only $\mathrm{CO}_{2}$ is used in the first stage to remove most of the hydrogen on the coke.

Coke gasification with $\mathrm{CO}_{2}$ is a promising method that can be used for $\mathrm{CO}_{2}$ reduction and $\mathrm{CO}$ production, in which metal additives can act as promoters to improve the gasification rate and reduce the gasification temperature. However, the decrease of catalyst activity and stability after several reaction-regeneration cycles is still a big challenge for $\mathrm{CO}_{2}$ gasification and requires further studies.

\subsection{Steam gasification}

Steam as gasifying agent in regeneration processes can also mitigate the accumulation of $\mathrm{CO}_{2}$ and produce syngas $\mathrm{CH}_{2}$ and CO). Steam gasification of coal or biomass is a well-known process widely applied [107-112]. However, when steam is used to remove coke deposited on catalyst at high temperature, it can destroy the structure of catalyst and cause permanent cat-

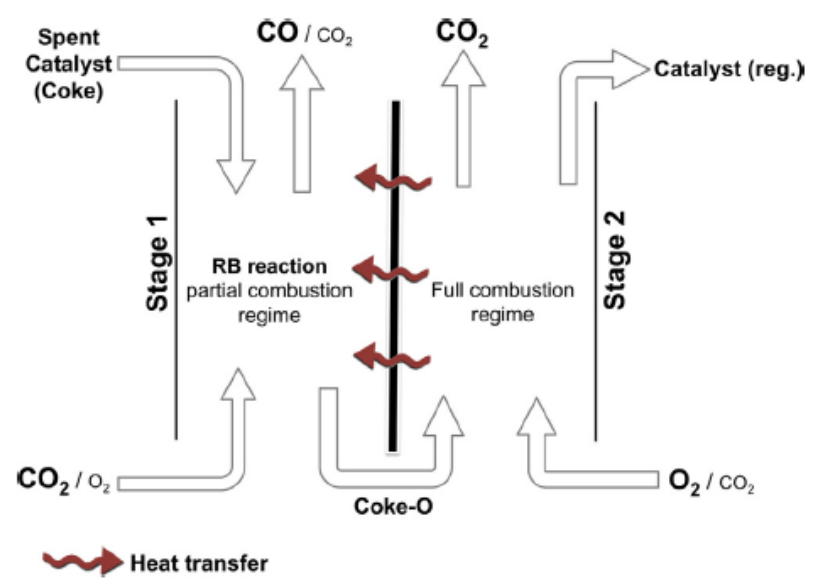

Fig. 6. Two-stage FCC regeneration system with diathermy wall providing heat transfer between the stages. Stage 1 favors RB reaction working with high $\mathrm{CO}_{2}$ and low $\mathrm{O}_{2}$ partial pressure. Stage 2 works at high $\mathrm{O}_{2}$ partial pressure to burn residual coke from stage 1 and provide heat for the overall FCC process [92], Copyright (2014) Elsevier. alyst deactivation. Hence, the catalyst must have an excellent hydrothermal stability. The scheme of coke gasification with steam can be described using Eq. (8).

$$
\mathrm{C}(\mathrm{s})+\mathrm{H}_{2} \mathrm{O}(\mathrm{g}) \rightarrow \mathrm{CO}(\mathrm{g})+\mathrm{H}_{2}(\mathrm{~g})+131 \mathrm{~kJ} / \mathrm{mol}
$$

The coke gasification rate (lignite and bituminous coal chars, commercial coke) with $\mathrm{H}_{2} \mathrm{O}$ is $2-5$ times higher than that with $\mathrm{CO}_{2}$ [113]. Tian et al. [88] also reported that the reactivity of steam gasification was about 3-5 times higher than that of $\mathrm{CO}_{2}$, removing coke from catalysts used for cracking heavy petroleum feeds at $800-900{ }^{\circ} \mathrm{C}$. Steam gasification of graphitic or less reactive coke species requires high temperatures of between $700-900{ }^{\circ} \mathrm{C}$, which, together with the hydrothermal instability of catalysts at that temperatures, restricts the practical use of steam gasification for coke removal in industrial processes.

Zhang et al. [114] observed that the steam gasification rate for spent FCC catalysts used in vacuum residue cracking was quite low, regenerating at temperatures below $700{ }^{\circ} \mathrm{C}$. Increasing the temperature to $800{ }^{\circ} \mathrm{C}$ improved the coke removal rate. The $\mathrm{H}_{2}$ and $\mathrm{CO}$ fraction in the product gas remained stable at 87 vol\%, independent of gasification temperature [114]. The steam gasification rate first increased, reached a maximum at coke conversions of $5 \%-20 \%$ and then slowly decreased $[115,116]$. Sahimi et al. [117] related the maximum in the steam gasification rate to the difference in initial pore volumes. During cracking, coke can deposit on both the external surfaces and the internal pores. The coke on the external surface reacts first with the steam and unblocks pores. Thereafter, the gasification rate reaches a maximum due to the increased contact area between coke and steam. As the steam gasification proceeds, the coke content gradually decreases, resulting in a lower gasification rate $[115,116]$.

Similar to $\mathrm{O}_{2}$ oxidization and $\mathrm{CO}_{2}$ gasification, the steam gasification rate can also be accelerated with metal or metal oxide additives [2]. Gorma et al. [72] observed that the coke deposited on typical FCC catalysts had a very low reactivity during steam gasification. Modifying the FCC catalyst with selected metals such as $\mathrm{La}, \mathrm{Ce}, \mathrm{Zn}, \mathrm{Ti}$ and Mn, can improve the gasification rate by $50 \%-150 \%$. Zhang et al. [118] added alkaline metal oxides into USY zeolites to create a bifunctional catalyst (BFC) and compared it with commercial FCC catalysts. They observed that the regeneration time for BFC was $50 \%$ shorter compared to commercial FCC catalysts, though the product gas compositions was almost unchanged. The gasification kinetics of these two catalysts were also evaluated. The activation energy of BFC was about $115 \mathrm{~kJ} / \mathrm{mol}$ lower than that of the commercial FCC catalyst $(150 \mathrm{~kJ} / \mathrm{mol})$, indicating that alkaline metal oxide doping can accelerate the gasification rate [119]. They also studied the effects of catalyst structure and operating parameters on steam coke gasification [120]. In their work, five different catalysts, FCC (Y-zeolite), BFC [118], K-BFC (doping K to adjust the catalyst acidity), A-FCC and A-FBC (steam pretreatment of the FCC and BFC catalysts at $800{ }^{\circ} \mathrm{C}$ for $14 \mathrm{~h}$ ), were used. Coke was gradually removed from these catalysts and the pore structure recovered. The product gas compositions during coke gasification at $800{ }^{\circ} \mathrm{C}$ were similar (Fig. 7(a)), however, the gasification rate over the K-BFC catalyst was the fastest due to the 

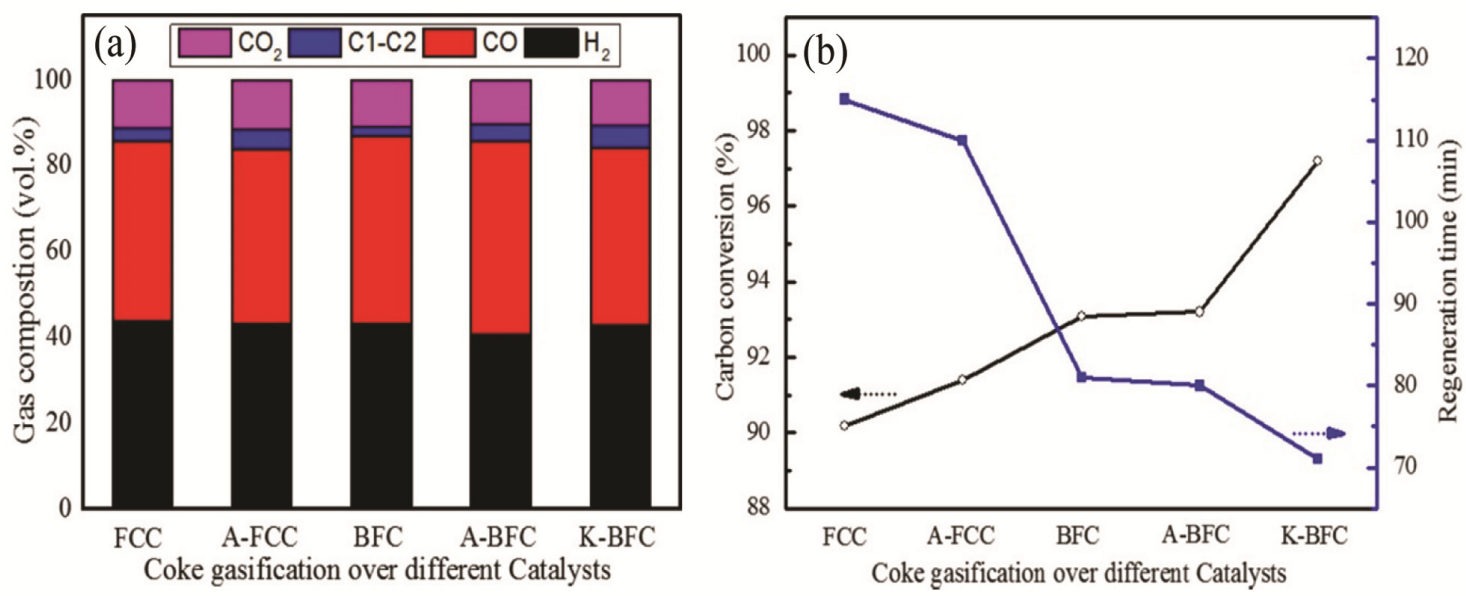

Fig. 7. Gas compositions (a) and coke conversion, regeneration time (b) of different catalysts during steam gasification at $800{ }^{\circ} \mathrm{C}$. Tests were carried out in a fluidized bed reactor and when the regeneration temperature was reached and stabilized, nitrogen was switched to steam for coke gasification [120], Copyright (2017) American Chemical Society.

well-developed pore structure, high alkaline oxide content, and effective additives (Fig. 7(b)) [120].

The integrated residual cracking and gasification (ICCG) process realizes the stepwise and value-added utilization of heavy oil and petroleum residues, producing syngas via coke gasification with steam, as shown in Fig. 8. Heavy oil is first cracked into volatiles, with the formation of coke at the same time. Then coke is gasified with steam, to produce syngas. The steam gasification can be simultaneously used to regenerate spent catalysts. Hydrogen is separated and used to hydrotreat the cracked oils. Regenerated catalyst particles can be recirculated to the reactor to provide the heat for catalytic cracking [120].

A similar process coupled the heavy oil catalytic cracking with coke gasification is also developed [121-123]. Due to the poor hydrothermal stability of typical FCC catalysts, a calcium aluminate catalyst was used in this process to facilitate coke gasification and reduce regeneration temperature [122]. This catalyst demonstrated, using coke gasification with steam below $800{ }^{\circ} \mathrm{C}$, that the $\mathrm{H}_{2}$ and $\mathrm{CO}_{2}$ fraction in the product gas could reach $81.5 \mathrm{vol} \%$, and coke removal was $93.6 \%$ [123]. The catalyst was still active after three reaction-regeneration cycles, suggesting that the calcium aluminate catalyst was suitable for this coupled process [123].

The effect of $\mathrm{O}_{2}$ on gasification activity and product gas composition was investigated. Zhang et al. [114] studied the coke removal from FCC catalysts, adding $5 \mathrm{vol} \% \mathrm{O}_{2}$ to the steam. $\mathrm{CO}_{2}$ was significantly increased and $\mathrm{H}_{2}$ reduced, while gasification time was only slightly shortened. Tian et al. [73] determined the effect of $\mathrm{O}_{2}$ concentration on the product gas distribution (Fig. 9), and discovered that the effect of steam in the gasification reaction was dramatically reduced if $\mathrm{O}_{2}$ concentration was sufficiently high. At $780{ }^{\circ} \mathrm{C}$, if the $\mathrm{O}_{2}$ partial pressure was lower than $2.0 \mathrm{kPa}$, the proportions of $\mathrm{CO}, \mathrm{H}_{2}$ and $\mathrm{CH}_{4}$ decreased, while $\mathrm{CO}_{2}$ proportion increased with increasing $\mathrm{O}_{2}$ concentration. However, as the partial pressure of $\mathrm{O}_{2}$ exceeded $13.8 \mathrm{kPa}$, the composition and proportion of product gas were similar to that in an $\mathrm{O}_{2}-\mathrm{N}_{2}$ atmosphere. They selected
$\mathrm{O}_{2}(2 \mathrm{kPa})$ and steam $(90 \mathrm{kPa})$ as the gas mixture to study kinetics and observed the activation energy decreasing from 230 $\mathrm{kJ} / \mathrm{mol}$ (pure steam) to $90 \mathrm{~kJ} / \mathrm{mol}$ and decided to better use the shrinking-core model rather than the homogeneous model to describe the gasification behavior. Using the BFC catalyst, Zhang et al. [119] introduced 3\% $\mathrm{O}_{2}$ to the steam and found a significant decrease in regeneration time. They showed, coke

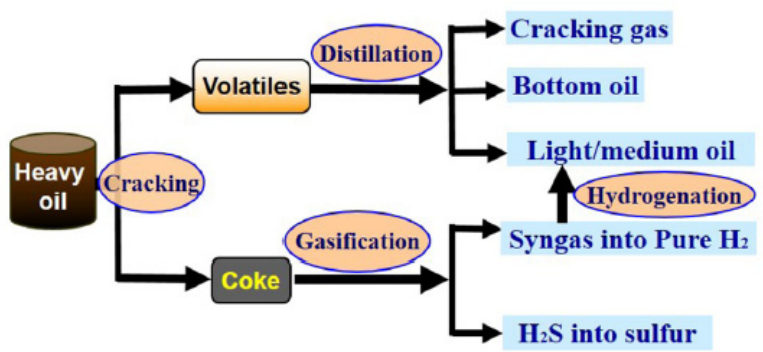

Fig. 8. Flow scheme for the integrated cracking and coke gasification process [120], Copyright (2017) American Chemical Society.

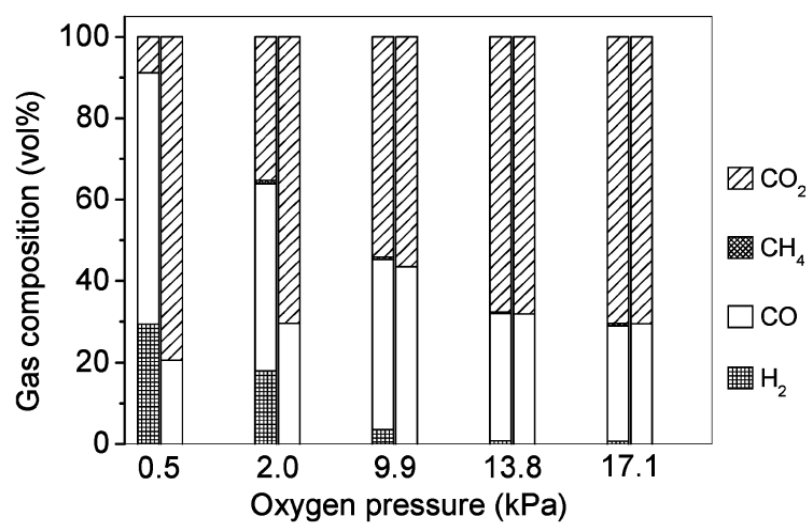

Fig. 9. Effect of $\mathrm{O}_{2}$ concentration on gas composition for coke gasification with steam- $\mathrm{O}_{2}$ (left column) and $\mathrm{O}_{2}-\mathrm{N}_{2}$ (right column) at $780{ }^{\circ} \mathrm{C}$ for $5 \mathrm{~min}$. The coked catalyst is heated for $30 \mathrm{~min}$ at $800^{\circ} \mathrm{C}$ under nitrogen flow for devolatilization pretreatment and then the volatiles removed [73], Copyright (2014) American Chemical Society. 
could be removed below $800{ }^{\circ} \mathrm{C}$ with pure steam in $30 \mathrm{~min}$, and using the gas mixture in $10 \mathrm{~min}$. The activation energy decreased from 115 to $45 \mathrm{~kJ} / \mathrm{mol}$ after introducing $3 \% \mathrm{O}_{2}$.

Coupling the steam gasification with $\mathrm{O}_{2}$ combustion is also used to control the heat balance in some processes. Gorma et al. [72] proposed a step-out improvement of FCC concept, in which the heat balance in the unit was optimized, removing large coke quantities in a regeneration process that coupled steam gasification with $\mathrm{O}_{2}$ combustion. However, it was difficult to obtain an adequate heat balance at certain gasification temperatures. A two-stage FCC regeneration process was presented by Tian et al. [88], in which catalyst coke was partially burnt with $\mathrm{O}_{2}$ in the first stage to release heat and increase the temperature of the catalyst particles. Subsequently, the residual coke was further gasified with steam in the second stage. However, Zhang et al. [115] pointed out that steam gasification should first be used to convert most of the deposited coke to syngas, followed by air combustion to completely remove the residual coke.

Coke deposited on the catalyst may even favor reactions of interest. For instance, coke could improve catalyst shape selectivity to increase specific product yields, reduce side reactions through selective poisoning of non-selective active sites, or promote catalytic activity through formation of new active centers, induced by certain coke species [124]. Therefore, it may not be necessary to remove coke completely in these cases. For example, the partial regeneration of the SAPO-34 catalyst via steam gasification benefited the yield of light olefins in the MTO process [125]. Steam gasification was more suitable for partial regeneration, because the residual coke was more effective, enhancing the ethylene selectivity compared to air combustion [125]. This new regeneration method not only maximizes the utilization of carbon atoms but also increases the targeted product selectivity, encouraging similar approaches in related industrial processes.

Although steam gasification has a higher reaction rate than $\mathrm{CO}_{2}$ gasification, it is limited to the hydrothermal stability of the catalyst. Therefore, steam gasification has been seldom used in industrial regeneration processes. The use of metal modified catalysts and $\mathrm{O}_{2}$-steam gas mixtures as regeneration gas enable the reduction of the steam gasification temperature. However, these applications need more detailed studies.

\section{Regeneration using hydrogenation}

Coke removal can also be realized by non-oxidative treatments, such as pyrolysis using inert gas $[38,126]$, or hydrocracking using hydrogen or alkanes [26,127]. Schulz et al. [128] reported that coke deposited on HZSM-5 catalysts could be completely removed by inert gas treatment at a temperature of $287^{\circ} \mathrm{C}$, but only partially removed at higher reaction temperatures of $327-377^{\circ} \mathrm{C}$. Magnoux et al. [126] found that coke deposited on USHY catalysts could be partly removed by $\mathrm{N}_{2}$ treatment, which caused the degree of residual coke aromaticity and catalyst deactivation to increase. In other words, whether the catalytic activity can be recovered or not after treatment with inert gas at high temperature remains ques- tionable. Therefore, in the following section, we mainly focus on catalyst regeneration using hydrocracking with hydrogen.

It was observed by Marecot et al. [129] that methane was the only product when an industrially coked $\mathrm{Pt} / \mathrm{Al}_{2} \mathrm{O}_{3}$ catalyst was regenerated under hydrogen atmosphere using a temperature programmed reaction. Therefore, the coke removal reaction with $\mathrm{H}_{2}$ can be described with Eq. (9).

$$
\mathrm{C}(\mathrm{s})+2 \mathrm{H}_{2}(\mathrm{~g}) \rightarrow \mathrm{CH}_{4}(\mathrm{~g}) \quad-75 \mathrm{~kJ} / \mathrm{mol}
$$

Walker et al. [130] found that the relative coke removal rate at $800{ }^{\circ} \mathrm{C}$ was in the order of $\mathrm{O}_{2}>\mathrm{H}_{2} \mathrm{O}>\mathrm{CO}_{2}>\mathrm{H}_{2}$, which means that $\mathrm{H}_{2}$ is relative inactive and coke regeneration with $\mathrm{H}_{2}$ is a time- and/or energy-consuming process. Han et al. [131] discovered that a Mo/HZSM- 5 catalyst coked by methane dehydroaromatization reactions could only be effectively regenerated with $\mathrm{H}_{2}$ at temperatures above $850{ }^{\circ} \mathrm{C}$. Bauer et al. [26] found that a spent HZSM-5 catalyst, used in methanol to hydrocarbon reactions, could be partially reactivated by hydrogen and alkanes treatment at $420^{\circ} \mathrm{C}$. This was the result of hydrogenation and hydrocracking reactions, increasing activity recovery and the $\mathrm{H} / \mathrm{C}$ ratio of residual coke. They attributed this to the acid zeolites used, which were able to activate hydrogen bonds and facilitate coke hydrocracking [26]. Aguayo et al. [38] observed that after $\mathrm{H}_{2}$ treatment of coked HZSM- 5 catalysts, the catalyst activity was restored, and the $\mathrm{H} / \mathrm{C}$ ratio slightly increased, suggesting that $\mathrm{H}_{2}$ minimizes coke dehydrogenation. However, Jong et al. [27] showed that coke deposited on HZSM-5 could not be completely removed, using $\mathrm{H}_{2}$ as regeneration gas, even at temperatures as high as $900^{\circ} \mathrm{C}$. Combining xenon adsorption and ${ }^{13} \mathrm{C}$ CP-MAS NMR spectra, they observed that internal coke near the Brønsted acid sites was removed preferentially to that on the external surface of the zeolite crystallites. This indicates that Brønsted acid sites play an important role in $\mathrm{H}_{2}$ regeneration treatments [27]. Bauer et al. [132] discovered that propane could also selectively remove coke from spent catalysts. They analyzed the coke removal mechanism of a spent HZSM-5 zeolites in the presence of hydrogen or alkanes. As illustrated in Fig. 10, after hydrogen/alkane treatment, internal active sites were reactivated while external coke remained [132].

The effectiveness of regeneration gas used at $500{ }^{\circ} \mathrm{C}$ to remove coke on spent $m$-xylene transformation USHY catalysts follows the order of air $>\mathrm{H}_{2}>\mathrm{N}_{2}$ [133]. Moreover, Benamar et al. [133] observed that the degree of coke removal with $\mathrm{H}_{2}$ treatment depended on the coke content deposited on the deactivated catalyst. After $\mathrm{H}_{2}$ treatment, 35\% coke was removed from the low coke containing sample and only $15 \%$ from a high coke containing sample. In their study on the regeneration of a coked mordenite catalyst, used for toluene disproportionation (TDP), Gnep et al. [134,135] found that $\mathrm{H}_{2}$ had a positive effect on coke removal and catalytic activity recovery. However, the removal degree was dependent on the $\mathrm{H} / \mathrm{C}$ ratio of the coke. The hydrogen reactivation was only successful for $\mathrm{H} / \mathrm{C}$ ratio of coke greater than 1.0. George et al. [136] observed that for a spent $\mathrm{NiMo} / \mathrm{Al}_{2} \mathrm{O}_{3}$ catalyst, used in gasoil hydroprocessing, coke could not completely be removed under a $\mathrm{H}_{2}$ atmosphere at $500{ }^{\circ} \mathrm{C}$. However, this was attributed to the coke property rather than the regeneration conditions. This finding was later 


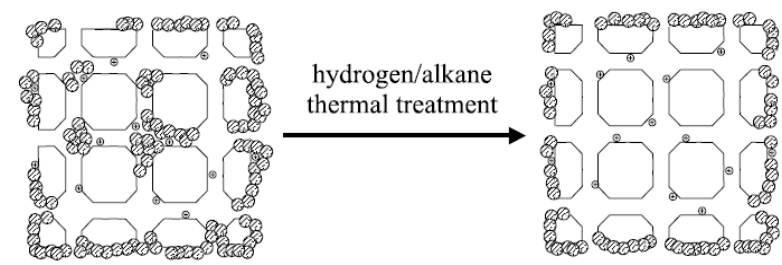

Fig. 10. Location of coke in spent HZSM-5 zeolite before and after hydrogen or alkane treatment. Acid sites are denoted by $\oplus[132]$, Copyright (2001) Elsevier.

confirmed by Silva et al. [137] in their regeneration studies on deactivated $\mathrm{NiMo} / \mathrm{Al}_{2} \mathrm{O}_{3}$ catalysts, using $\mathrm{H}_{2}$ at $400{ }^{\circ} \mathrm{C}$. They concluded that $\mathrm{H}_{2}$ treatment could only remove the soft or soluble portion of the coke, without affecting any harder coke. Note that the harder the coke, the lower the $\mathrm{H} / \mathrm{C}$ ratio. Consequently, the $\mathrm{H} / \mathrm{C}$ ratio of coke influences coke regeneration with $\mathrm{H}_{2}$ treatment.

However, more experiments verified that the removal of coke depends on the coke property can be eliminated by operating at lower temperature and elevated pressure. More than $40 \%$ coke could be removed, treating a deactivated MTO SAPO-34 catalyst with $\mathrm{H}_{2}$ at a pressure of $4 \mathrm{MPa}$ and a temperature of $450{ }^{\circ} \mathrm{C}$. The residual coke species were analyzed by GC-MS before and after the $\mathrm{H}_{2}$ treatment and phenanthrene and pyrene were the main species before $\mathrm{H}_{2}$ treatment. After $\mathrm{H}_{2}$ treatment, phenanthrene and pyrene were significantly reduced and light aromatics increased [16]. These results indicate that heavy aromatics are more active and hydrogenated much easier. In a study on the regeneration of a Co/Mo hydrodesulfurization catalyst, Snape et al. [138] distinguished the coke as soft and hard coke, and found that hard coke could be partially removed under a pressure of $15 \mathrm{MPa}$ and a temperature of $500{ }^{\circ} \mathrm{C}$. Weitkamp et al. $[127,139]$ studied the influence of temperature and hydrogen pressure on the regeneration of a spent Pt $(0.4 \%) /$ La-Y catalyst used for isobutane/butane alkylation. They observed that, as coke content decreased from 3 to $0.2 \mathrm{wt} \%$, catalyst activity was fully restored under a hydrogen pressure of 15 bar and temperatures of up to $300^{\circ} \mathrm{C}$. As shown in Fig. 11, both the conversion and the product composition were virtually identical after four alkylation and regeneration cycles, proving that the regeneration efficiency using $\mathrm{H}_{2}$ treatment was sufficient [139].

Pt-based catalysts, widely used for propane dehydrogenation, are rapidly deactivated by coke deposition. Sun et al. [140] compared the effectiveness of different gases $\left(\mathrm{H}_{2}, \mathrm{~N}_{2}\right.$, and air) on the regeneration of coked Pt-based catalysts, and catalysts regenerated with $\mathrm{H}_{2}$ demonstrated the best stability. It was observed that not only the harder coke was removed, but also the $\mathrm{H} / \mathrm{C}$ ratio of the residual coke increased, which was in agreement with previous work [26,29]. For the regeneration of coked cresol deoxygenation $\mathrm{Pt} / \gamma-\mathrm{Al}_{2} \mathrm{O}_{3}$ catalysts, Zanuttini et al. [141] confirmed the effectiveness of $\mathrm{H}_{2}$ treatment was strongly depended on temperature.

The efficiency of $\mathrm{H}_{2}$ regeneration for coked Mo/HZSM- 5 catalysts used for methane dehydroaromatization (MDA) should be emphasized, because the coke could be transformed to $\mathrm{CH}_{4}$

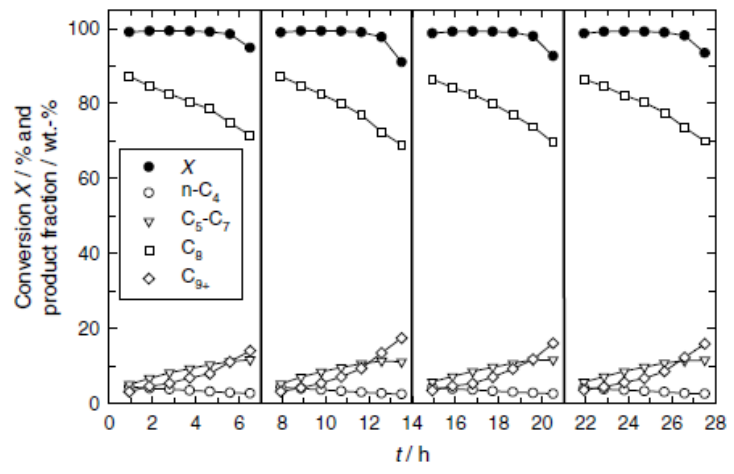

Fig. 11. Several alkylation/regeneration cycles of $0.4 \% \mathrm{Pt} / \mathrm{La}-\mathrm{Y}$ zeolite. The alkylation reaction was conducted for $7 \mathrm{~h}$ at $75^{\circ} \mathrm{C}$ and 20 bar in a fixed bed reactor. The regeneration was carried out for $7.25 \mathrm{~h}$ at a hydrogen pressure of 15 bar and $300{ }^{\circ} \mathrm{C}$ [139], Copyright (2004) Elsevier.

[142-144]. Moreover, at a certain reaction temperature, coke could be hydrogenated with $\mathrm{H}_{2}$ [145]. Honda et al. [142] conducted a series of switching experiments with $\mathrm{CH}_{4}$-reaction and $\mathrm{H}_{2}$-regeneration cycles over a (3 $\mathrm{wt} \%$ ) Mo/HZSM-5 catalyst at $700{ }^{\circ} \mathrm{C}$ in a fixed bed. They discovered that coke formed during the reaction could be removed under $\mathrm{H}_{2}$ atmosphere, and consequently the catalytic activity was completely recovered. The long-term stability ( $>1000 \mathrm{~h}$ ) of Mo/HZSM-5 catalysts in MDA reactions with periodic $\mathrm{CH}_{4}-\mathrm{H}_{2}$ switching at $760-800{ }^{\circ} \mathrm{C}$ was reported by Sun et al. [146]. They showed that the regeneration with $\mathrm{H}_{2}$ could effectively remove the almost inert aromatic-type coke, which might be applied to practical processes [146]. Xu et al. proposed the tripled-bed [147] and two-bed [148] circulat-

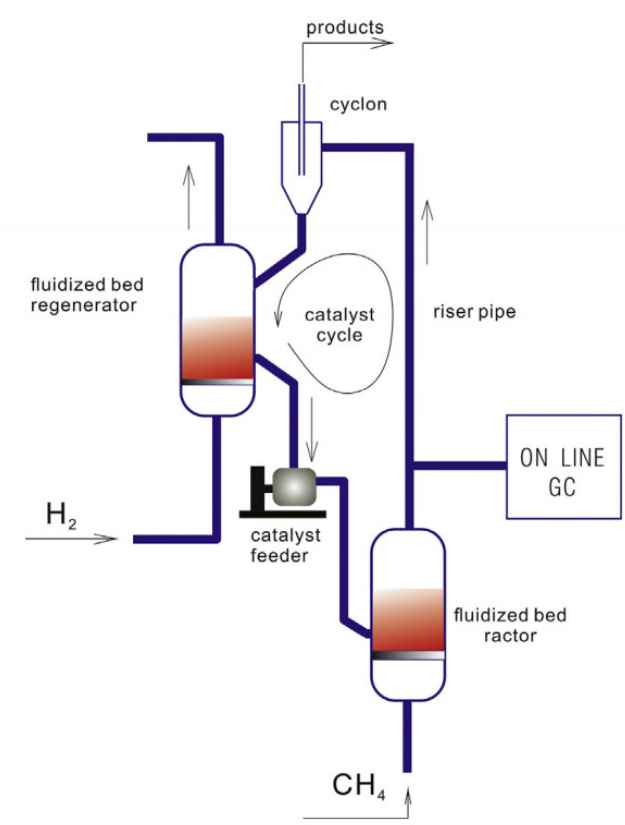

Fig. 12. A schematic of the $\mathrm{CH}_{4}$-reacton/ $\mathrm{H}_{2}$-regeneration fluidized bed system. This system consists of two fluidized bed reactors, a cyclone separator, a catalyst feeder, and an on-line GC system. The $\mathrm{CH}_{4}$-reaction VHSV was $3600 \mathrm{~mL} /(\mathrm{h} \cdot \mathrm{g})$ and the $\mathrm{H}_{2}$-regeneration VHSV was 900 $\mathrm{mL} /(\mathrm{h} \cdot \mathrm{g})$. Reaction temperature and regeneration temperature were both $800^{\circ} \mathrm{C}$, catalyst circulation speed was $9 \mathrm{~g} / \mathrm{min}$ [144], Copyright (2018) Elsevier. 
Table 2

Coke removal with different regeneration gases.

\begin{tabular}{lccccc}
\hline Regeneration gas & Heat effect & Temperature $\left({ }^{\circ} \mathrm{C}\right)$ & Pressure & Gas product & Challenges \\
\hline Air $/ \mathrm{O}_{2}$ & Exothermic & $>500$ & Atmospheric & $\mathrm{CO}_{2} / \mathrm{CO}_{2} \mathrm{H}_{2} \mathrm{O}$ & $\mathrm{Hot} \mathrm{spots} \mathrm{and} \mathrm{CO}$ emission \\
$\mathrm{O}_{3} / \mathrm{NO}_{x}$ & Exothermic & $50-400$ & Atmospheric & $\mathrm{CO}_{2} / \mathrm{H}_{2} \mathrm{O} / \mathrm{NO}_{x}$ & Harmful gases and CO \\
$\mathrm{CO}_{2}$ & Endothermic & $>700$ & Atmospheric & $\mathrm{CO}$ & $\mathrm{High}$ temperature \\
$\mathrm{H}_{2} \mathrm{O}(\mathrm{g})$ & Endothermic & $>700$ & Atmospheric & $\mathrm{CO} / \mathrm{H}_{2}$ & High temperature \\
$\mathrm{H}_{2}$ & Exothermic & $>700$ & Elevated pressure & $\mathrm{CH}_{4}$ & High temperature or pressure \\
\hline
\end{tabular}

ing fluidized bed system, serving as $\mathrm{CH}_{4}$ converter and $\mathrm{H}_{2}$ regenerator. Yan et al. [144] developed a pilot-scale $\mathrm{CH}_{4}$-reaction and $\mathrm{H}_{2}$-regeneration fluidized bed system (Fig. 12) and demonstrated with 8-h continuous tests that the catalyst activity was stable throughout the entire experimental period.

In summary, deactivated catalysts can be regenerated with $\mathrm{H}_{2}$ and internal coke located near acid sites is preferentially removed. This could improve the coke-induced selectivity of HZSM-5 catalysts [132]. However, the complete removal of coke with $\mathrm{H}_{2}$ needs severe operating conditions, such as high pressure and/or high temperature.

Although the coke deposited on catalysts can be removed via oxidation, gasification and hydrogenation, air is typically used in industrial processes to regenerate deactivated catalysts, because moderate regeneration temperatures can be applied. Ozone and oxynitride can lower the regeneration temperature, but they are harmful gases and their emissions are strictly controlled. Coke gasification with carbon dioxide or steam can transform the low-value coke into value-added syngas and simultaneously reduce the carbon dioxide emission. However, coke gasification is a highly endothermic reaction, which needs high temperatures that may destroy the catalyst structure. Coke can also be removed with hydrogen at high temperatures or pressures. The characteristics and challenges of these regeneration methods are summarized in Table 2.

\section{Conclusions and outlook}

Coke deposition is inevitable in catalytic processes and can eventually lead to catalyst deactivation. Therefore, regeneration processes are necessary to restore catalyst activity and to ensure continuous operation in industrial processes. In this review, the current progress of regeneration methods such as oxidation (air, ozone and oxynitride), gasification (carbon dioxide and water steam) and hydrogenation (hydrogen) is reviewed, to indicate how catalysts and their related processes can be further optimized. Catalyst type, coke property and location are important parameters that affect catalyst regeneration. Metal addition can significantly increase the regeneration activity of certain methods. However, metals can also act as poisons and lead to catalyst deactivation at higher temperatures. Although significant progress has been made in catalyst regeneration, it is worth to further study and develop optimal methods for coke removal. Future research might include: (1) intrinsic regeneration kinetics that consider the catalytic active sites, (2) the synthesis of catalysts with excellent thermal and hydrothermal stability, and coke removal with carbon dioxide and water steam gasification at high temperature, (3) additive addition (metals) to lower the regeneration temperature, which might also cause catalyst deactivation (the role of additives should be further studied), (4) catalytic processes with partial regeneration that not only increase carbon utilization, but also improve product selectivity. Stability of partially regenerated catalysts after repeated reaction-regeneration cycles should attract a great deal of attention. There is no doubt that co-feeding regeneration agents (water and hydrogen) can reduce coke to some extent and prolong catalyst lifetime. Since regeneration temperatures are always higher than reaction temperatures, coke formation rates are always greater than coke removal rates during catalytic processes, eventually causing catalyst deactivation. If regeneration temperatures can effectively be reduced, or whether a balance between coke formation rate and removal rate can be realized is debatable. If it can be performed, we could realize an advanced catalytic process without catalyst deactivation. Therefore, improving coking resistance and increasing coke-removing activity of catalysts remain challenges to be solved by both academia and industry.

\section{References}

[1] M. Guisnet, F. R. Ribeiro, Deactivation and Regeneration of Zeolite Catalysts, Imperial College Press, London, 2011.

[2] M. D. Argyle, C. H. Bartholomew, Catalsts, 2015, 5, 145-269.

[3] C. H. Bartholomew, M. D. Argyle, Catalsts, 2015, 5, 949-954.

[4] C. H. Bartholomew, Appl. Catal. A, 2001, 212, 17-60.

[5] S. T. Sie, Appl. Catal. A, 2001, 212, 129-151.

[6] P. Dufresne, Appl. Catal. A, 2007, 322, 67-75.

[7] D. L. Trimm, Appl. Catal. A, 2001, 212, 153-160.

[8] C. H. Bartholomew, Catalyst Deactivation and Regeneration, 5nd ed., Provo, 2000, 5, 255-232.

[9] M. Guisnet, P. Magnoux, Catal. Today, 1997, 36, 477-483.

[10] M. Guisnet, L. Costa, F. R. Ribeiro, J. Mol. Catal. A, 2009, 305, 69-83.

[11] M. Guisnet, P. Magnoux, Stud. Surf. Sci. Catal., 1994, 88, 53-68.

[12] M. Guisnet, P. Magnoux, Appl. Catal. A, 2001, 212, 83-96.

[13] A. de Lucas, P. Canizares, A. Durán, A. Carrero, Appl. Catal. A, 1997, 156, 299-317.

[14] S. S. Gao, S. T. Xu, Y. X. Wei, Q. L. Qiao, Z. C. Xu, X. Q. Wu, M. Z. Zhang, Y. L. He, S. L. Xu, Z. M. Liu, J. Catal., 2018, 367, 306-314.

[15] S. S. Arora, D. L. S. Nieskens, A. Malek, A. Bhan, Nat. Catal., 2018, 1, 666-672.

[16] X. B. Zhao, J. Z. Li, P. Tian, L. Y. Wang, X. Li, S. F. Lin, X. W Guo, Z. M. Liu, ACS Catal., 2019, 9, 3017-3025.

[17] S. Mahamulkar, K. Yin, P. K. Agrawal, R. J. Davis, C. W. Jones, A. Malek, H. Shibata, Ind. Eng. Chem. Res., 2016, 55, 9760-9818.

[18] C. A. Querini, Catal. Today, 2000, 62, 135-143. 


\section{Graphical Abstract}

Chin. J. Catal., 2020, 41: 1048-1061 doi: 10.1016/S1872-2067(20)63552-5

\section{Regeneration of catalysts deactivated by coke deposition: A review}

Jibin Zhou, Jianping Zhao, Jinling Zhang, Tao Zhang, Mao Ye *, Zhongmin Liu Dalian Institute of Chemical Physics, Chinese Academy of Sciences; University of Chinese Academy of Sciences

The current progress of regeneration methods such as oxidation, gasification and hydrogenation was reviewed to identify, where catalyst designs can be improved and their related processes optimized.

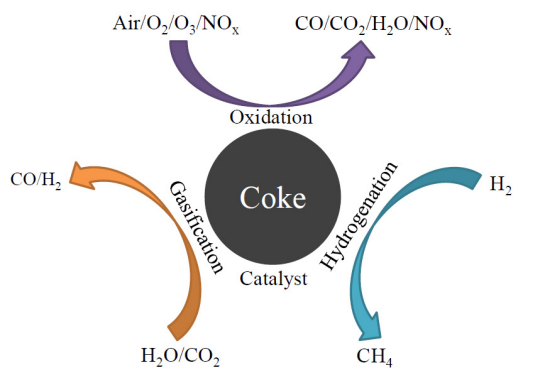

[19] L. Carlton, R. G. Copperthwaite, G. J. Hutchings, E. C. Reynhardt, J. Chem. Soc., Chem. Commun., 1986, 1008-1010.

[20] H. A. Abdullah, A. Hauser, F. A. Ali, A. Al-Adwani, Energy Fuel, 2006, 20, 320-323.

[21] R. Cortés-Torres, E. Y. Nolasco-Terrón, O. Olea-Mejia, V. Varela-Guerrero, C. E. Barrera-Díaz, E. Cuevas-Yañez, Catal. Today, 2018, 305, 126-132.

[22] A. Baiker, Chem. Rev., 1999, 99, 453-474.

[23] L. M. Petkovic, D. M. Ginosar, K. C. Burch, J. Catal., 2005, 234, 328-339.

[24] L. M. Petkovic, D. M. Ginosar, D. N. Thompson, K. C. Burch, ACS Sym. Ser., 2007, 13,169-179.

[25] M. Y. He, Y. H. Sun, B. X. Han, Angew. Chem. Int. Ed., 2013, 52, 9620-9633.

[26] F. Bauer, H. Ernst, E. Geidel, R. Schödel, J. Catal., 1996, 164, 146-151.

[27] S. J. Jong, A. R. Pradhan, J. F. Wu, T. C. Tsai, S. B. Liu, J. Catal., 1998, 174, 210-218.

[28] J. O. Barth, A. Jentys, J. A. Lercher, Ind. Eng. Chem. Res., 2004, 43, 3097-3104.

[29] B. Behera, S. S. Ray, Catal. Today, 2009, 141, 195-204.

[30] C. Kern, A. Jess, Chem. Eng. Sci., 2005, 60, 4249-4264.

[31] P. Tian, Y. X. Wei, M. Ye, Z. M. Liu, ACS Catal., 2015, 5, 1922-1938.

[32] L. Y. Jia, A. Farouha, L. Pinard, S. Hedan, J. D. Comparot, A. Dufour, K. B. Tayeb, H. Vezin, C. Batiot-Dupeyrat, Appl. Catal. B, 2017, 219, 82-91.

[33] M. H. Lei, F. Lesage, M. A. Latifi, S. Tretjak, Comp.-Aided. Chem. Eng., 2015, 37, 335-340.

[34] M. D. P. Sørensen, Chem. Eng. Sci., 2017, 168, 465-479.

[35] P. Magnoux, M. Guisnet, Appl. Catal., 1988, 38, 341-352.

[36] G. A. D. Nassionou, P. Magnoux, M. Guisnet, Microporous Mesoporous Mater., 1998, 22, 389-398.

[37] K. Moljord, P. Magnoux, M. Guisnet, Appl. Catal. A, 1995, 121, 245-259.

[38] A. T. Aguayo, A. G. Gayubo, J. Ereña, A. Alaitz, J. Bilbao, Ind. Eng. Chem. Res., 2003, 42. 3914-3921.

[39] A. T. Aguayo, A. G. Gayubo, A. Atutxa, M. Olazar, J. Bilbao, J. Chem. Technol. Biotechnol., 1999, 74, 1082-1088.

[40] J. M. Ortega, A. G. Gayubo, A. T. Aguayo, P. L. Benito, J. Bilbao, Ind. Eng. Chem. Res., 1997, 36, 60-66.

[41] N. Zhu, Y. Liu, Y. Wang, F. Q. Chen, X. L. Zhan, Ind. Eng. Chem. Res., 2009, 49, 89-93.

[42] K. Moljord, P. Magnoux, M. Guisnet, Catal. Lett., 1994, 28, 53-59.
[43] T. J. Keskitalo, K. J. T. Lipiäinen, A. O. I. Krause, Ind. Eng. Chem. Res., 2006, 45, 6458-6467.

[44] Y. Nakasaka, T. Tago, H. Konno, A. Okabe, T. Masuda, Chem. Eng. J., 2012, 207, 368-376.

[45] S. B. He, J. Q. Li, B. Wang, X. H. Dai, C. L. Sun, Z. W. Bai, Q. Guo, K. Seshan, Appl. Catal. A, 2016, 513, 82-88.

[46] C. A. Querini, S. C. Fung, Appl. Catal. A, 1994, 117, 53-74.

[47] S. Kim, E. Sasmaz, J. Lauterbach, Appl. Catal. B, 2015, 168, 212-219.

[48] M. R. H. Siddiqui, S. Holmes, H. He, W. Smith, E. N. Coker, M. P. Atkins, I. V. Kozhevnikov, Catal. Lett., 2000, 66, 53-57.

[49] I. V. Kozhevnikov, S. Holmes, M. R. H. Siddiqui, Appl. Catal. A, 2001, 214, 47-58.

[50] C. L. Pieck, R. J. Verderone, E. L. Jablonski, J. M. Parera, Appl. Catal., 1989, 55, 1-10.

[51] C. L. Pieck, J E. L. Jablonski, R. J. Verderone, J. M. Grau, J. M. Parera, Catal. Today, 1989, 5, 463-472.

[52] A. T. Aguayo, J. Ereña, I. Sierra, M. Olazar, J. Bilbao, Catal. Today., 2005, 106, 265-270.

[53] T. Furusawa, Y. Miura, Y. Kori, M. Sato, N. Suzuki, Catal. Commun., 2009, 10, 552-556.

[54] P. Lu, Q. X. Huang, Y. Chi, J. H. Yan, Energy Fuels, 2017, 31, 8283-8290.

[55] G. J. Hutchings, R. G. Copperthwaite, T. Themistocleous, G. A. Foulds, A. S. Bielovitch, B. J. Loots, G. Nowitz, P. Van Eck, Appl. Catal., 1987, 34, 153-161.

[56] J. Biswas, I. E. Maxwell, Appl. Catal., 1990, 63, 197-258.

[57] C. Royo, J. M. Perdices, A. Monzon, J. Santamaria, Ind. Eng. Chem. Res., 1996, 35, 1813-1823.

[58] R. G. Copperthwaite, G. J. Hutchings, P. Johnston, S. W. Orchard, J. Chem. Soc. Farad. Trans 1., 1986, 82, 1007-1017.

[59] P. S. Monneyron, S. Mathe, M. H. Manero, J. N. Foussard, Chem. Eng. Res. Des., 2006, 81, 289-295.

[60] C. L. Pieck, C. A. Querini, J. M. Parera, Appl. Catal. A, 1997, 165, 207-218.

[61] L. Mariey, J. Lamotte, T. Chevreau, J. C. Lavalley, React. Kinet. Catal. Lett., 1996, 59, 241-246.

[62] C. L. Pieck, E. L. Jablonski, J. M. Parera, Stud. Surf. Sci. Catal., 1994, 88, 289-295.

[63] C. L. Pieck, C. R. Vera, C. A. Querini, J. M. Parera, Appl. Catal. A, 2005, 278, 173-180.

[64] R. Richard, C. Julcour, M. H. Manero, Ozone-Sci. Eng., 2017, 39, 366-373.

[65] S. Khangkham, C. Julcour-Lebigue, S. Damronglerd, C. Ngamcha- 
russrivichai, M. H. Manero, H. Delmas, Appl. Catal. B, 2013, 140, 396-405.

[66] P. Monneyron, S. Mathé, M. H. Manero, J. N. Foussard, Chem. Eng. Res. Des., 2003, 81, 1193-1198.

[67] D. P. Ivanov, V. I. Sobolev, G. I. Panov, Appl. Catal. A, 2003, 241, 113-121.

[68] K. Barbera, S. Sørensen, S. Bordiga, J. Skibsted, H. Fordsmand, P. Beato, T. V. Janssens, Catal. Sci. Technol., 2012, 2, 1196-1206.

[69] L. F. de Mello, R. D. Pimenta, G. T. Moure, O. R. Pravia, L. Gearhart, P. B. Milios, T. Melien, Energy. Procedia., 2009, 1, 117-124.

[70] L. Tavares dos Santos, F. M. Santos, R. S. Silva, T. S. Gomes, P. M. Esteves, R. D. Pimenta, S. M. Menezes, O. R. Chamberlain, Y. L. Lam, M. M. Pereira, Appl. Catal. A, 2008, 336, 40-47.

[71] S. C. Pereira, F. Franco, F. Ribeiro, N. Batalha, M. M. Pereira, Appl. Catal. B, 2016, 196, 117-126.

[72] A. Corma, L. Sauvanaud, E. Doskocil, G. Yaluris, J. Catal., 2011, 279, 183-195.

[73] G. Tian, G. Wang, C. M. Xu, J. S. Gao, Energy Fuels, 2014, 28, 1372-1379.

[74] M. B. Ansari, S. E. Park, Energy Environ. Sci., 2012, 5, 9419-9437.

[75] T. C. da Silva, R. P. dos Santos, N. Batalha, M. M. Pereira, Catal. Commun., 2014, 51, 42-45.

[76] M. Kawakami, T. Karato, T. Takenaka, S. Yokoyama, ISIJ Int., 2005, 45, 1027-1034.

[77] R. Khalil, G. Várhegyi, S. Jäschke, M. G. Grønli, J. Hustad, Energy Fuels, 2008, 23, 94-100.

[78] P. Lahijani, Z. A. Zainal, M. Mohammadi, A. R. Mohamed, Renew. Sust. Energy Rev., 2015, 41, 615-632.

[79] J. Hunt, A. Ferrari, A. Lita, M. Crosswhite, B. Ashley, A. E. Stiegman, J. Phys. Chem. C, 2013, 117, 26871-26880.

[80] X. D. Xu, J. A. Moulijn, Energy Fuels, 1996, 10, 305-325.

[81] M. Mikkelsen, M. Jørgensen, F. C. Krebs, Energy Environ. Sci., 2010, 3, 43-81.

[82] S. M. Campbell, D. M. Bibby, J. M. Coddington, R. F. Howe, R. H. Meinhold, J. Catal., 1996, 161, 338-349.

[83] M. Müller, G. Harvey, R. Prins, Microporous Mesoporous Mater., 2000, 34, 135-147.

[84] C. S. Triantafillidis, A. G. Vlessidis, N. P. Evmiridis, Ind. Eng. Chem. Res., 2000, 39, 307-319.

[85] S. Ergun, J. Phys. Chem., 1956, 60, 480-485.

[86] S. R. Kelemen, H. Freund, J. Catal., 1986, 102, 80-91.

[87] H. Freund, Fuel., 1986, 65, 63-66.

[88] G. Tian, G. Wang, C. M. Xu, J. S. Gao, Ind. Eng. Chem. Res., 2013, 52, 16737-16744.

[89] D. D. Feng, Y. Zhang, Y. J. Zhao, S. Z. Sun, J. M. Gao, Fuel Process. Technol., 2018, 172, 106-114.

[90] S. R. Mirzabekova, G. T. Farkhadova, A. K. Mamedov, M. I. Rustamov, React. Kinet. Catal. Lett., 1992, 48, 225-231.

[91] A. L. Sun, Z. F. Qin, J. G. Wang, Appl. Catal. A, 2002, 234, 179-189.

[92] T. C. D. Silva, J. F. Pinto, F. M. Santos, L. T. D. Santos, D. A. G. Aranda, F. Ribeiro, N. Batalha, M. M. Pereira, Appl. Catal. B, 2015, 164, 225-233.

[93] S. C. Pereira, M. F. Ribeiro, N. Batalha, M. M. Pereira, Greenh. Gases: Sci. Technol., 2017, 7, 843-851.

[94] P. O'Connor, A. C. Pouwels, Stud. Surf. Sci. Catal., 1994, 88, 129-144.

[95] J. Sehested, Catal. Today, 2006, 111, 103-110.

[96] Q. L. Xu. F. Peng, Q. Wei, H. Kai, S. Z. Xin, Y. J, Yan, Int. J. Hydrogen Energy, 2019, 44, 10277-10285.

[97] L. Bednarczuk, P. Ramirez de la Piscina, N. Homs, Int. J. Hydrogen Energy, 2015, 40, 5256-5263.

[98] L. Bednarczuk, P. Ramirez de la Piscina, N. Homs, Int. J. Hydrogen
Energy, 2016, 41, 19509-19517.

[99] B. Rego de Vasconcelos, D. P. Minh, P. Sharrock, A. Nzihou, Catal. Today, 2018, 310, 107-115.

[100] S. Takenaka, K. Otsuka, Chem. Lett., 2001, 218-219.

[101] S. Takenaka, K. Otsuka, Y. Tomikubo, K. Otsuka, J. Catal., 2003 219, 176-185.

[102] S. Takenaka, Y. Tomikubo, E. Kato, K. Otsuka, Fuel, 2004, 83, 47-57.

[103] D. B. Ingram, U. P. Paul, US 9664385, 2017.

[104] F. Alenazey, C. G. Cooper, C. B. Dave, S. S. E. H. Elnashaie, A. A. Susu, A. A. Adesina, Catal. Commun., 2009, 10, 406-411.

[105] B. Marchon, W. T. Tysoe, J. Carrazza, H. Heinemann, G. A. Somorjai, J. Phys. Chem., 1988, 92, 5744-5749

[106] W. P. Hettinger Jr, Catal. Today, 1999, 53, 367-384.

[107] T. Zhang, M. D. Amiridis, Appl. Catal. A, 1998, 167, 161-172.

[108] T. Takarada, Y. Tamai, A. Tomita, Fuel, 1985, 64, 1438-1442.

[109] A. Molina, F. Mondragon, Fuel, 1998, 77, 1831-1839.

[110] E. G. Baker, L. K. Mudge, M. D. Brown, Ind. Eng. Chem. Res., 1987, 26, 1335-1339.

[111] J. Wang, M. Jiang, Y. Yao, Y. Zhang, J. Cao, Fuel, 2009, 88, 1572-1579.

[112] H. de Lasa, E. Salaices, J. Mazumder, R. Lucky, Chem. Rev., 2011, 111, 5404-5433.

[113] M. F. Irfan, M. R. Usman, K. Kusakabe, Energy, 2011, 36, 12-40.

[114] Y. M. Zhang, D. P. Yu, W. L. Li, Y. Wang, S. Q. Gao, G. W. Xu, Ind. Eng. Chem. Res., 2012, 46, 15032-15040.

[115] Y. M. Zhang, D. P. Yu, W. L. Li, S. Q. Gao, G. W. Xu, H. Q. Zhou, J. Chen, Appl. Energy, 2013, 112, 1318-1325.

[116] Y. M. Zhang, G. Q. Sun, S. Q. Gao, G. W. Xu, Procedia Eng., 2015, 102, 1758-1765.

[117] M. Sahimi, T. T. Tsotsis, Chem. Eng. Sci., 1988, 43, 113-121.

[118] Y. M. Zhang, D. P. Yu, W. L. Li, S. Q. Gao, G. W. Xu, Fuel, 2014, 117, 1196-1203.

[119] Y. M. Zhang, M. Q. Yao, G. Q. Sun, S. Q. Gao, G. W. Xu, Ind. Eng Chem. Res., 2014, 53, 6316-6324.

[120] Y. M. Zhang, L. Huang, X. C. Zhang, G. Q. Sun, S. Q. Gao, S. Zhang, Energy Fuels, 2017, 31, 7438-7444.

[121] R. Y. Tang, Y. Y. Tian, Y. Y. Qiao, H. F. Zhou, G. M. Zhao, Fuel Process. Technol., 2016, 153, 1-8.

[122] J. H. Zhang, Y. J. Che, Z. B. Wang, Y. Y. Qiao, Y. Y. Tian, Energy Fuels, 2016, 30, 6701-6711.

[123] R. Y. Tang, M. Yuan, K. F. Liu, J. T. Zhang, Y. Y. Tian, J. Energy Inst., 2019, 92, 1936-1943.

[124] C. H. Collett, J. Mcgregor, Catal. Sci. Technol., 2016, 6, 363-378.

[125] J. B. Zhou, J. L. Zhang, Y. C. Zhi, J. P. Zhao, T. Zhang, M. Ye, Z. M. Liu, Ind. Eng. Chem. Res., 2018, 57, 17338-17347.

[126] P. Magnoux, H. S. Cerqueira, M. Guisnet, Appl. Catal. A, 2002, 235, 93-99.

[127] R. Klingmann, R. Josl, Y. Traa, R. Gläser, J. Weitkamp, Appl. Catal. $A$, 2005, 281, 215-223.

[128] H. Schulz, M. Wei, Microporous Mesoporous Mater., 1999, 29, 205-218.

[129] P. Marecot, S. Peyrovi, D. Bahloul, J. Barbier, Appl. Catal., 1990, 66, 181-190.

[130] P. L. Walker Jr, S. Matsumoto, T. Hanzawa, T. Muira, I. M. K. Ismail, Fuel, 1983, 62, 140-149.

[131] S. J. Han, S. K. Kim, A. Hwang, S. Kim, D. Y. Hong, G. Kwak, K. W. Jun, Y. T. Kim, Appl. Catal. B, 2019, 241, 305-318.

[132] F. Bauer, W. H. Chen, Q. Zhao, A. Freyer, S. B. Liu, Microporous Mesoporous Mater., 2001, 47, 67-77.

[133] A. Benamar, Z. Bechket, Y. Boucheffa, A. Miloudi, C. R. Chim., 2009, 12, 706-715 
[134] N. S. Gnep, M. L. M. de Armando, M. Guisnet, React. Kinet. Catal. Lett., 1980, 13, 183-189.

[135] T. C.Tsai, Appl. Catal. A, 2006, 301, 292-298.

[136] Z. M. George, P. Mohammed, R Tower, In: Proceedings of the 9th International Congress on Catalysis, 1988, 230-237.

[137] V. L. S. Teixeira da Silva, F. P. Lima, L. C. Dieguez, M. Schmal, Ind. Eng. Chem. Res., 1998, 37, 882-886.

[138] C. E. Snape, M. C. Diaz, Y. R. Tyagi, S. C. Martin, R. Hughes, Stud. Surf. Sci. Catal., 2001, 139, 359-365.

[139] R. Josl, R. Klingmann, Y. Traa, R. Gläser, J. Weitkamp, Catal. Commum., 2004, 5, 239-241.

[140] C. Y. Sun, J. Y Luo, M. J. Cao, P. Zheng, G. C. Li, J. H. Bu, Z. Cao, S. H. Chen, X. W. Xie, J. Energy Chem., 2018, 27, 311-318.

[141] M. S. Zanuttini, M. A. Peralta, C. A. Querini, Ind. Eng. Chem. Res.,
2015, 54, 4929-4939.

[142] K. Honda, T. Yoshida, Z. G. Zhang, Catal. Commum., 2003, 4, 21-26.

[143] Y. Y. Shu, H. T. Ma, R. Ohnishi, M. Ichikawa, Chem. Commum., 2003, 1, 86-87.

[144] P. Yan, Z. G. Zhang, D. P. Li, X. Cheng, X. Z. Zhang, F. Yang, C. F. Huang, X. X. Ma, Chin. J. Chem. Eng., 2018, 26, 1928-1936.

[145] Z. G. Zhang, Carbon Resources Conversion., 2019, 808, 2588-9133.

[146] C. Y. Sun, G. Z. Fang, X. G. Guo, Y. L. Hu, S. Q. Ma, T. H. Yang, J. Han, H. Ma, D. L. Tan, X. H. Bao, J. Energy Chem., 2015, 24, 257-263.

[147] Y. B. Xu, J. Y. Lu, J. D. Wang, Y. Suzuki, Z. G. Zhang, Chem. Eng. J., 2011, 168, 390-402.

[148] Y. B. Xu, Y. Song, Z. G. Zhang, Catal. Today, 2017, 279, 115-123.

\title{
积碳失活催化剂的再生
}

周吉涁 ${ }^{\mathrm{a}, \mathrm{b}}$, 赵建平 ${ }^{\mathrm{a}, \mathrm{b}}$ ，张今令 ${ }^{\mathrm{a}}$ ，张 涛 ${ }^{\mathrm{a}}$, 叶 茂 ${ }^{\mathrm{a},{ }^{*}}$, 刘中民 ${ }^{\mathrm{a}}$

a 中国科学院大学化学物理研究所, 甲醇制烯烃国家工程实验室, 大连洁净能源国家实验室,

能源材料化学协同创新中心, 辽宁大连 116023

b中国科学院大学, 北京100049

\begin{abstract}
摘要: 催化反应常伴随着积碳的生成, 而积碳又可以通过覆盖催化剂酸性位点或者堵塞催化剂孔道而引起催化剂失活, 表 现为产物选择性的降低. 根据不同的失活机理可以将催化剂失活分为永久性失活和可逆性失活, 而积碳失活一般是可逆 的, 可以通过再生的方式来除去积碳并恢复催化剂活性. 对于工业生产而言, 为了保证反应的连续运行, 失活催化剂的及 时再生是非常必要的. 尽管前人已经做了大量的研究, 并尝试不同的再生方法来除去催化剂积碳, 但发展一种操作简单、 高效和经济的再生方法仍然是一个巨大的挑战. 目前工业催化剂积碳失活后最常用的再生手段是氧化再生, 其主要以空 气或氧气为再生气体, 将积碳转化为一氧化碳、二氧化碳和水等. 但空气或氧气氧化再生为强放热反应, 放出的大量热量 及生成的水蒸气会对催化剂的组分及结构带来一定的影响. 虽然以臭氧和氮氧化物为再生气体可以有效降低再生温度, 但是作为有毒有害气体, 它们的排放受到严格的限制, 这也阻碍了其进一步工业化应用. 与氧化再生相比, 二氧化碳或水 蒸气气化再生可以有效降低再生过程中的放热量, 并将无价值的积碳转化为高品质的合成气, 同时减少二氧化碳的排放. 但由于二氧化碳和水蒸气的氧化性较弱, 需要较高的再生温度, 对催化剂的水热稳定性提出了更高的要求. 此外, 在氢气 气氛下, 可以通过加氢裂解除去积碳, 但同样需要较高的再生温度或压力. 通过添加金属或金属氧化物等添加剂, 可以有 效降低再生温度并增加再生速率, 但也可能会引起催化剂中毒, 造成催化剂的永久性失活, 所以需要严格控制添加剂的含 量. 本文分析了目前常用的几种再生方法的优缺点及面临的挑战, 并对未来的研究重点及研究方向进行了展望.
\end{abstract}

关键词: 催化剂; 积碳; 失活; 再生; 氧化; 气化; 加氢

收稿日期: 2019-09-30. 接受日期: 2019-11-16. 出版日期: 2020-07-05.

*通讯联系人. 电话: (0411)84379618; 电子信箱: maoye@dicp.ac.cn

基金来源: 国家自然科学基金(91834302).

本文的电子版全文由Elsevier出版社在ScienceDirect上出版(http://www.sciencedirect.com/science/journal/18722067). 